\title{
The Role of Low-Angle Extensional Tectonics, Flat Fracture Domains, and Gravity Slides in Hydrothermal and EGS Resources of the Western United States
}

\author{
Final Technical Report \\ DE-FG36-04G014296
}

Principal Investigator: Joseph Moore; Energy and Geoscience Institute; 801-585-6931; jmoore@egi.utah.edu

Technical Contact Shirley Streff, 801-585-9763; Energy and Geoscience Institute; sstreff@egi.utah.edu

DOE Project Officer: Jay Nathwani; 303-275-4756; jay.nathwani@go.doe.gov DOE Contract Spec: Pete Simon; 303-275-4787; pete.simon@go.doe.gov

This project had three sets of objectives. The objective of Phase 1 is based on the original Statement of Work. At the direction of DOE Project Manager, the Statement of Work was modified twice prior to the completion of the project (Phases 2 and 3). These modifications were requested to better address changes in DOE's goals.

\section{Project Objectives and Tasks}

Phase 1: The initial objective of this project was to integrate field observations and a detailed analysis of crystalline-rock-hosted, flat-lying thermal aquifers at Steamboat Springs and other geothermal fields to develop a comprehensive understanding of subhorizontal fracture domains in the Basin and Range province in the context of: natural thermal-fluid flow; production or injection strategies; potential for artificial stimulation Results of the project are anticipated to be highly useful to geothermal operators and explorationists for locating and developing such lowangle aquifers in natural systems, and for encouraging currently subcommercial thermal-fluidaquifers to produce via artificial stimulation utilizing Enhanced Geothermal System (EGS) technology.

\section{Phase 2:}

In FY 2008, the scope of the project was modified for the first time. The renegotiated project consisted of four tasks:

Task 1 - Inventory and evaluation of holdings

The purpose of this task was to update inventory of Geothermal Sample Library holdings and identify information and gaps that could be filled to ensure that the Geothermal Sample Library 
has the information that the geothermal industry requires to successfully develop engineered geothermal systems (EGS).

Task 2 - Scanning of documents and core

The Geothermal Sample Library contains a wealth of public-domain information that is currently stored in filing cabinets. The data includes reports, well logs, maps, and other information that could be extremely valuable to the U.S. geothermal industry as they seek to develop EGS systems in the U.S. EGI will scan these documents to create electronic copies. Where applicable, these electronic files will then undergo an optical character recognition (OCR) process that will make them searchable. If feasible with the available budget, EGI will consider generating scans of selected core, and also make those available electronically.

Task 3 - Create web-based GIS and library catalog interface

EGI will construct an electronic catalog of the Geothermal Sample Library holdings. This will be made accessible to the general public. The user will be able to search the documents electronically and download the available information directly from the web.

Task 4 - Develop outreach and technology transfer plan In this task, EGI will develop an outreach and technology transfer plan to see that the Geothermal Sample Library is fully used by government agencies and the geothermal community.

\section{Phase 3:}

The objectives of the project were again modified for FY 2009 to provide support and assistance on the Desert Peak EGS stimulation experiment. In particular, EGI was asked to assist in a variety of geologic studies including: 1) mineral and lithologic investigations; 2) preparation of geologic cross sections; and 3) integration of geologic and temperature data.

\section{Project Overviews and Results}

\section{Phase 1:}

Background: The Steamboat Springs geothermal system provides the most dramatic example of subhorizontal thermal-fluid aquifers in crystalline rock in the Basin and Range, but this is by no means an isolated case. Similar but more diffuse subhorizontal permeability has been reported at Roosevelt Hot Springs and Cove-Fort Sulphurdale, Utah; and a km-scale gravity-slide block channels injectate at Dixie Valley, Nevada.

Some fossil hydrothermal systems in the Basin and Range also show evidence of shallowdipping fracture permeability, even when the effects of stress-field re-orientation are taken into account. The Comstock gold-silver district, just a few kilometers west of Steamboat Springs, produced mainly from ore bodies localized in a normal fault zone dipping at only $30-35^{\circ}$ over much of its 20 -km strike length. There is a well-exposed set of regional-scale, late Miocene low- 
angle faults and associated brecciation and hydrothermal alteration that can serve as an exposed analogue for low-angle faulting deeply concealed in the Steamboat Springs system.

Four geothermal wells were geologically logged in detail. Three are production wells (78-29, 4232, and 34-32) and one is an injection well (64A-32) (see Johnson and Hulen, 2005, 2006 and Appendix 1). Prior to this work, the only geologic information available for any of these wells was from "mud logs". Each well penetrated a productive fluid-entry zone in Cretaceous granite at a similar elevation. In these wells, the production interval occurred in a narrow depth range between 240 and $275 \mathrm{~m}$. The "mud logs" for the four production wells show nothing particularly anomalous in the geologic character of the production zone, other than these are zones of lost circulation.

The detailed logging reveals that in every instance, the approach to the main production zone was signaled by increasingly intense: quartz-clay-sericite alteration; fault gouge and microbreccia development; shearing; slickensiding; hydrothermal veining and breccias; and sulfide mineralization. There was good evidence for multiple periods of mineralization and alteration, as well as for at least some fracturing and slickensiding post-dating alteration and mineralization. Schlumberger MicroImager (FMI) logs were completed for some of the wells, and these logs showed evidence for the fluid entries occurring within low-angle fracture zones.

The new geologic logging efforts have revealed the presence of at least four additional zones of hydrothermal alteration, mineralization, gouge development, slickensiding, brecciation, and shearing in each well at equivalent elevations. These are interpreted as hydrothermally altered low-angle fault zones above the main thermal aquifer. The only difference is that these zones are not currently productive; they have been hydrothermally sealed and not sufficiently disrupted to support commercial production.

The injection well, 64A-32, was drilled to intersect the principal injection zone (which accommodates several million pounds per hour of spent production fluid) in the depth interval of 550 to $580 \mathrm{~m}$. The zone was penetrated at the anticipated depth. Examination of the available cuttings (there were also many "no-return" zones) showed that cuttings above and within the injection zone contained significant amounts of molybdenite $\left(\mathrm{MoS}_{2}\right)$ and chalcopyrite associated with intense brecciation, silicification and clay-sericite alteration of the host granite. Chips from the molybdenite-chalcopyrite -bearing zone are commonly coated with euhedral quartz. The zone is interpreted to be a large breccia pipe developed in a Mesozoic porphyry molybdenumcopper system.

\section{Phase 2: Significant Results}

During the course of this phase of the project 2543 reports including text, figures and large format enclosures, 1428 maps, and 698 well logs were scanned. The information is stored in a Microsoft Access Database on the Geothermal Server. The following information was captured for each document:

- EGI Ref - Unique identifier for each record

- Title

- Continent 
- Country

- State/Province

- Nonregional - Topic if no location information was available

- Date

- Author

- Company/Source

- Document Type

- Report Number

- Library Shelf Location

\section{Phase 3:}

In this phase of the project detailed geologic cross sections of the Desert Peak geothermal field were developed to identify the structural controls on the geothermal system and locate possible fluid flow paths. The results of this work were published by Lutz and others (2009, Appendix 1) in the Stanford Reservoir Engineering Conference Proceedings.

\section{References:}

Johnson, S.D., and Hulen, J.B., 2005, Geologic observations bearing on low-angle fractures and gravity-slide blocks in the Steamboat Hills and Steamboat geothermal field, Washoe County, Nevada: Geothermal Resources Council Transactions, v. 29, p. 281-289.

Johnson, S.D., and Hulen, J.B., 2006, A dual hypothesis for thermal-fluid advection in the northern Steamboat geothermal field, Nevada - upflow in ancient breccia pipes; distributed outflow in a low-angle extensional fault zone: Geothermal Resources Council Transactions, v. 30, p. 87-96.

Lutz, S. J., Moore, J. N., Jones, C. G., Suemnicht, G. A. and Robertson-Tait, A., 2009, Geological and structural relationships in the Desert Peak geothermal system, Nevada: implications for EGS development: Proceedings, Thirty-Fourth Workshop on Geothermal Reservoir Engineering Stanford University, Stanford, California, February 9-11, 2009, p. 205212. 


\title{
Geologic Observations Bearing on Low-Angle Fractures and Gravity-Slide Blocks in the Steamboat Hills and Steamboat Geothermal System, Washoe County, Nevada
}

\author{
Stuart D. Johnson ${ }^{1}$ and Jeffrey B. Hulen² \\ ${ }^{1}$ ORMAT Nevada Inc, Sparks, NV sjohnson@ormat.com \\ ${ }^{2}$ Energy \& Geoscience Inst., Univ. of Utah, Salt Lake City, UT jhulen@egi.utah.edu
}

\section{Keywords}

Flat-fracture domains, low-angle faulting, detachment faulting, gravity slides, landslides, tectonic history, volcanic history, hydrothermal history, siliceous sinter, fault kinematics, Steamboat Hills

\begin{abstract}
Geothermal systems within the Basin and Range have been attributed to deep-circulation and heating of fluids associated with Quaternary, often range-bounding fault systems. These faults are typically described as high angle with dips in the range of 65 degrees. There is growing evidence that flat-fracture domains exert significant control on the distribution of geothermal fluids in portions of these systems and in some cases may be the most significant control on distribution of geothermal fluids at commercial drilling depths. As the significance of low-angle faults becomes more evident in hydrothermal systems, it becomes equally imperative that this faulting style is understood in terms of Enhanced Geothermal Development (EGS).

The distribution of geothermal fluids in the Steamboat Hills Geothermal area is clearly controlled by flat-fracture domain. Preliminary investigation has defined low-angle structures at local outcrop scale as well as suspected gravity slide block features that locally affect the distribution of hydrothermal fluids. On a district scale, permissive evidence of large scale low-angle faulting has been found in well-bore drill cuttings. Recent observations from shallow drilling as well as recently excavated bedrock exposures are described and documentation of gravity slide block features is presented.
\end{abstract}

\section{Introduction}

The significance of low-angle fracture domains in geothermal systems, and the potential to stimulate such structures for Enhanced Geothermal System (EGS) development (e.g., Nathwani and Creed, 2002), are subjects that have barely been broached. Yet these structures could be among the most important thermohydrologic elements in many high-temperature geothermal systems (for example, Roosevelt, Utah; Bruhn et al., 1982) in the western United States. The premier example of likely low-angle-fracture-controlled thermal-fluid flow is the Steamboat Hills (SBH) system, near Reno, Nevada. This system is hosted principally by Mesozoic crystalline igneous and metamorphic rocks, yet its most productive thermal aquifers are surprisingly yet demonstrably subhorizontal (e.g., Sorey and Colvard, 1992; Mariner and Janik, 1995; DeRocher, 1996). In this paper, we: (1) present results of our preliminary investigation of the nature and origin of these flat-fracture domains at the surface and in geothermal wells at Steamboat; and (2) describe exposed examples of numerous confirmed and likely SBH gravity-slide blocks, in particular as the outcropping architecture of these features bears on the possible configuration of major thermal-fluid channels at depth. Our work has been greatly facilitated by recent and ongoing excavation for a new geothermal plant a new interstate highway through the SBH. The resulting high-quality bedrock exposures in the typically "float"-covered SBH have made possible significant revisions in thinking about the geologic history of these unusual hills as well as the subsurface permeability architecture controlling the area's productive, moderate- to high-temperature geothermal system.

\section{Regional Geologic Setting}

The eponymously-named SBH geothermal system circulates beneath a $20 \mathrm{~km}^{2}$, ENE-trending group of low-relief, rounded, and hummocky hills just slightly apart from the steep eastern Sierra Nevada (here, the Carson Range) range front, and about $20 \mathrm{~km} \mathrm{SSE}$ of Reno, Nevada (Figure 1, overleaf). The SBH are part of the Carson Segment of the Walker Lane (Stewart, 1988), a complex, $100 \mathrm{~km}$-wide (at this latitude), NW-trending structural belt separating the Sierra Nevada microplate from the "typical" Basin and Range (north- to NEaligned narrow mountains and valleys; e.g., Parsons, 1995) to the east. The Carson Segment is characterized by NE-trend- 
ing, high-angle, left-lateral strike-slip and oblique-slip faults believed to facilitate displacement transfer between the steep oblique-slip fault zone at the eastern margin of the Sierra block and the NW-trending strike-slip faults that are the signature features of the Walker Lane.

The oldest rocks exposed within the Carson Segment are Late Triassic to Jurassic metasiliciclastic and metavolcanic rocks (Stewart, 1999), intruded extensively by Jurassic to Cretaceous stocks, plugs, and dikes ranging in composition from diorite to granite, and emplaced as satellitic plutons flanking the giant composite Sierra Nevada batholith. These older rocks are overlain unconformably by the medial to distal portions of regional, Oligocene to early Miocene, felsic ignimbrite sheets erupted from caldera sources farther to the east and southeast. Overlying the erosionally dissected ash-flow tuffs are andesitic to dacitic flows and flow breccias and minor lacustrine sedimentary rocks of the 18-15 Ma Alta Formation (Castor et al., 2002). Intrusive equivalents of the Alta flows, including the Davidson diorite in the nearby Comstock mining district, are locally preserved and exposed. The Alta is overlain by a second, similar, major intermediate-composition volcanic sequence, the 15-12 Ma Kate Peak Formation, that is somewhat more felsic overall, ranging to rhyodacite (Vikre et al., 1988; Castor et al., 2002). Younger volcanic units throughout the Carson Segment are much more local in distribution and only marginally germane here; those found in and around the SBH will be noted later in this report.

\section{Geology and Thermohydrology of the Steamboat Hills and Vicinity}

The geology of the Steamboat Hills (Figure 1 and Figure 2) has been described in some detail in White et al. (1964) and White (1968), classic documents that provide the groundwork for the following synopsis and discussion. Mesozoic (probably Triassic) siliciclastic to calcareous metasedimentary rocks and minor intermediatecomposition metavolcanic rocks throughout the area are intruded by a composite stock consisting perhaps of at least three phases of hornblendeand or- biotite-bearing "Sierran" granodiorite to granite of late Cretaceous age (see also Flynn et al., 1993). These rocks are overlain locally in the study area by andesitic flows, flow breccias, and lahars assigned both to the Alta and Kate Peak Formations (Figure 1). The 2.5 Ma Lousetown [basaltic] Andesite unconformably overlies the Alta and Kate Peak, and includes olivine basalt flows as well as pyroxene andesite. Cinder cones assigned to the Lousetown mark vent locations at the crest of the SBH. The SBH are co-aligned with a series of 1.15-1.52 Ma rhyolitic volcanic centers (Silberman et al., 1979) extending from the SW crest of the hills (Figure 1) to a point about $15 \mathrm{~km}$ ENE. The pumiceous, $1.15 \mathrm{Ma}$ rhyolite dome in the $\mathrm{SBH}$ is believed to be too old to be associated with a felsic magma chamber

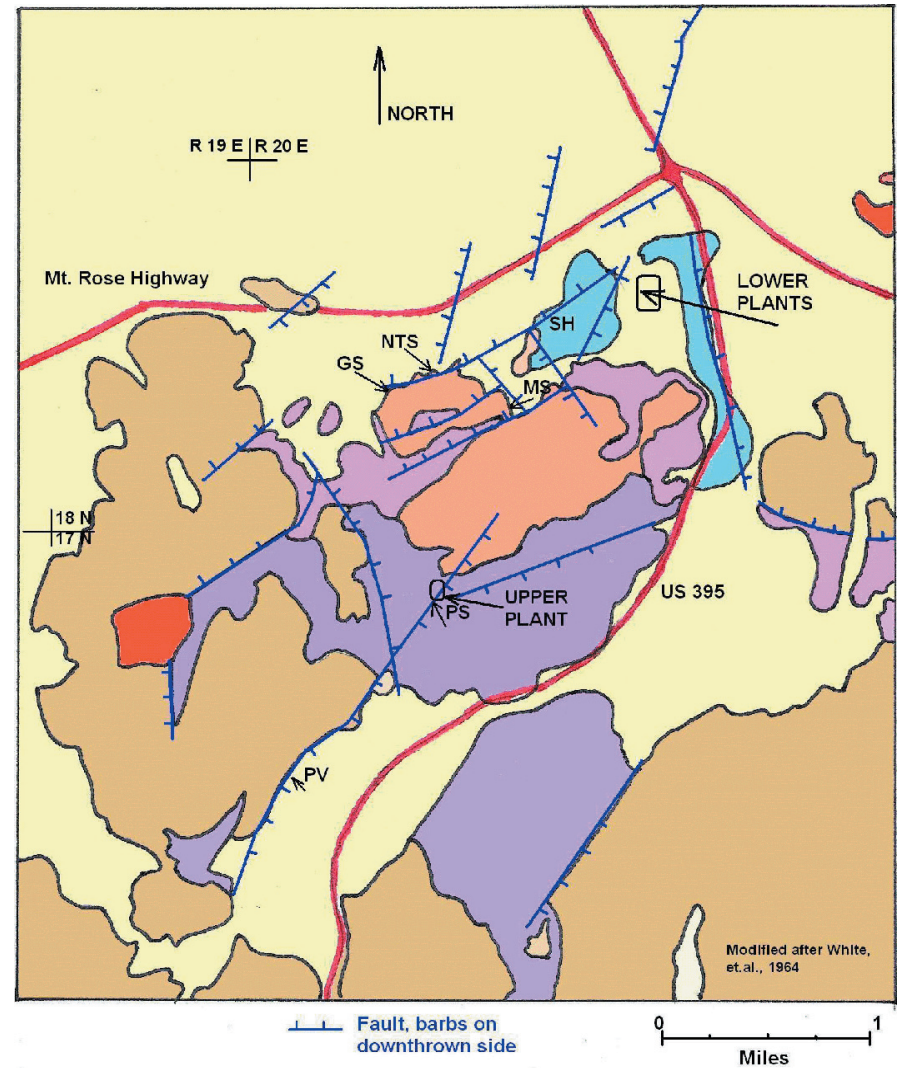

Figure 1. Generalized geologic map for the Steamboat Hills. Locations discussed in text are noted: SH (Sinter Hill), GS (Galena Slide), NTS (Nevada Thermal Slide), MS (Mercury Slide), PS (Plant Slide), PV (Pleasant Valley Slide). See Figure 2 for lithologic descriptions.
Generalized Geologic Column for the Steamboat Hills Geothermal Area

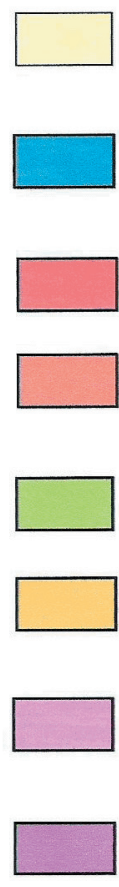

Alluvium

Recent and Quaternary deposits that include alluvial fan deposits, stream gravels, and lake deposits. Older alluvium includes gracial outwash. Opal-cemented gravels are included in vicinity of hot spring activity.

\section{Sinter Deposits}

Includes older chalcedonic sinters that may pre-date Lousetown basaltic andesites. Progressively younger sinters are less chalcedonic (Pleistocene age?). While youngest sinters are dominantly opaline and are considered to by mid-Pleistocene to Recent in age.

\section{Steamboat Hills Rhyolite}

Pliocene to Pleistocene domes of extrusive pumiceous rhyolite. Sparse phenocrysts of sanidine, quartz, plagioclase and biotite. Dated @ 1.1 mya.

Lousetown Basaltic Andesite

Basalts and basaltic andesite forming gray to dark gray flows. Includes pyroxene andesite and olivine basalts. Thin flows up to $80^{\prime}$ thick with vesicular tops. Cinder cones define vent area in upper SBH. Pliocene or Pleistocene in age. Dated @ 2.5 mya.

Kate Peak Formation

Miocene or Pliocene age and includes lavas, flow breccias and tuff breccias composed of hornblende andesite, biotite-hornblende andesite and pyroxine andesite. Typically forms reddish-brown outcrops with modest alteration

Alta Formation

Oligocene? age. Includes soda trachyte, hornblende andesite and pyroxene andesites. Typically forms purple to black outcrop and shows strong alteration.

\section{Sierran Grano-diorite}

Cretaceous age plutonic intrusives. Dominantly grano-diorite but includes some quartz monzonite, aplite dikes and pegmatites. Intensely altered and silicified in vicinity of hot spring and fumarole activity.

\section{Mesozoic Metasediments}

Triassic? age. Includes tuffaceous siltstones, quartzites and conglomerates. Contact zones with grano-diorite include schist, hornfels and slates.

Figure 2. Generalized geologic column for the Steamboat Hills mapped units shown in Figure 1 
still providing heat for the active geothermal system. However, such a chamber could readily have supported the system (or a prior incarnation thereof) in the not-toodistant past.

Recent geologic mapping and borehole-cuttings logging at Steamboat have revealed additional details about the geologic setting of the SBH. First, the Steamboat sinters locally overlie diatomaceous lake sediments. The diatomites and the sinters alike are in contact with glassy unaltered young andesite, the sparse occurrences of which do not permit confident characterization of the mode of emplacement. We suspect that the glassy andesite occurs either as subvolcanic dikes, or as the chilled portions of flows that were erupted

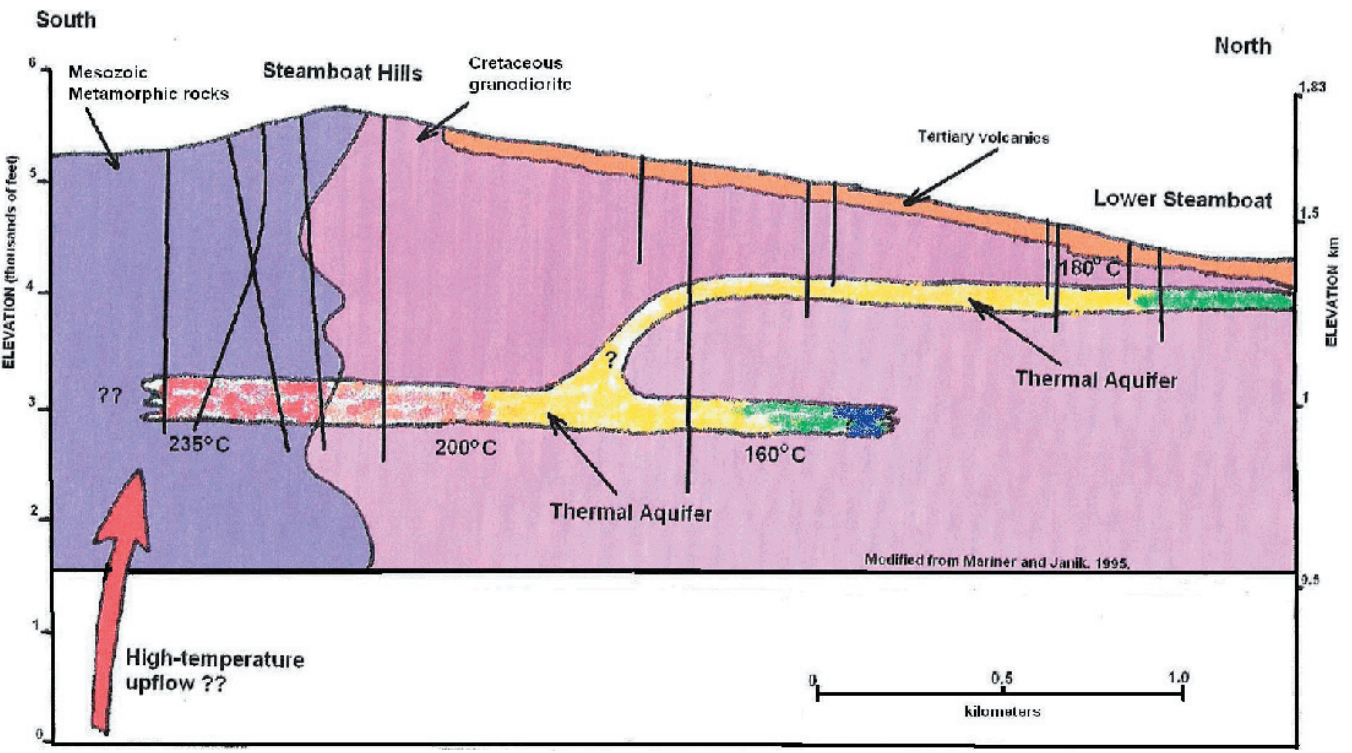

Figure 3. Schematic north-south cross-section through the Steamboat Hills showing thermal aquifers within granodiorite and metamorphic section.

into small, diatomaceous lakes. The glassy andesite appears to be contemporaneous with or younger than the oldest of the famous siliceous sinters of the SBH. All the above units are locally blanketed by Pleistocene to Holocene surficial deposits including fan and stream gravels, glacial outwash, and lacustrine sediments; gravels near the sinter deposits are locally opal-cemented.

Siliceous sinters, steaming ground, fumaroles, and associated advanced argillic alteration are the principal surface manifestations of still vigorous hydrothermal activity in the $\mathrm{SBH}$. The sinters range from wholly chalcedonic blankets that likely pre-date the Lousetown Andesite to entirely opaline varieties considered to be mid-Pleistocene to Holocene in age. The thickest of the sinter accumulations clearly mark major long-lived discharge zones for the SBH geothermal system. The advanced argillic, or "acid-sulfate" alteration affects mostly Cretaceous granodiorite along with andesitic rocks of the Alta and Kate Peak Formations. This type of alteration, in the extreme case, is notable for complete destruction of all major rock-forming phases except quartz, resulting in a soft, commonly whitish and powdery aggregate dominated by kaolinite and alunite (Schoen and White, 1967; Schoen et al., 1974), and locally accompanied by a little native sulfur and cinnabar. In shallow boreholes sited in this type of alteration, the advanced argillic minerals give way with depth first to a less acid-stable, montmorillonite-rich argillic assemblage, then to propylitically-altered and/or silicified to (rarely) adularized protoliths. The silicified rocks also crop out extensively in the vicinity of Sinter Hill (Figure 1).

High-angle faults mapped or inferred from photolinears in the mostly "float"-covered SBH are of three principal orientations - northeast, northwest, and northerly (White et al., 1964). Normal-displacement, high-angle faults of the latter orientation - so-called "Basin-Range"-style structures - are clearly associated with the prominent late Quaternary siliceous sinter terraces of the same general orientation at the easternmost edge of the SBH just west of U.S. Highway 395 (Figure 1). However, within these sinters, the most recently discharged, silica-depositing thermal waters clearly exited from northwest-trending, high-angle tension gashes. These openspace fractures may be consequential to listric faulting that defines the NE margins of the Steamboat Hills. The northwesttrending and northeast-trending faults mirror, respectively: 1) the right-lateral, strike-slip, principal displacement zones of the Walker Lane Belt; and 2) the left-lateral strike-slip to oblique-slip faults kinematically linked to those zones (see above and Stewart, 1988).

The Geothermal System - Although high-angle faults appear to prevail at the surface in the $\mathrm{SBH}$, the principal producing thermal-fluid aquifers at depth are clearly subhorizontal structures (Figure 3; DeRocher, 1996; van de Kamp and Goranson, 1990; Sorey and Colvard, 1992; and Mariner and Janik, 1995). These structures form two tiers: a deeper, higher-temperature $\left(200-235^{\circ} \mathrm{C}\right)$ aquifer at an average depth of about $900 \mathrm{~m}$ in the vicinity of the "upper power plant" (Figure 1); and a shallower, moderate-temperature $\left(155-180^{\circ} \mathrm{C}\right)$ aquifer tapped at $275 \mathrm{~m}$ for the "lower power plants" in the northeastern SBH. De Rocher (1996) and van de Kamp and Goranson (1990) suggested that these aquifers are the productive portions of two separate geothermal systems. Sorey and Colvard (1992) and Mariner and Janik (1995), on the other hand, provided compelling evidence that the two "tiers" are actually interconnected major conduits in the same system.

Well HA-4 typifies production from the shallower thermal aquifer in the northeastern SBH. This well, located on the eastern flank of Sinter Hill (Figure 1), produces about 8000 liters per minute of dilute ( $\sim 3000 \mathrm{ppm}$ TDS), sodium-chloride thermal water at a temperature of about $155^{\circ} \mathrm{C}$ from a major fracture zone in granodiorite at a depth of about $250 \mathrm{~m}$. Characteristically for this part of the geothermal field, temperatures below the producing fracture show a slight progressive reversal down to the well's total depth. A number of cored slim holes 
(e.g., Flynn et al., 1993) have been drilled in this portion of the field, and the structures controlling major fluid entries in these holes are fracture zones in which individual open fractures have apertures up to several centimeters wide.

Major hot upflow zones feeding the lower and upper tiers of the SBH geothermal system have yet to be discovered. It has long been assumed that the "parent" upflow for the system is within or near the upper SBH development area (e.g., Mariner and Janik, 1995), but no deep wells in this area have encountered good evidence for such a feeder. The primary source of heat for the feeder is probably deep circulation, but, based on results of helium-isotope analysis, Kennedy (2003) believes that there could be a minor magmatic-gas input to the Steamboat production fluids.

Silberman et al. (1979), based on spatial relationships between alteration, siliceous sinter, and radiometrically dated volcanic rocks, have estimated the age of the SBH hydrothermal system to be 0.1-3 Ma. These authors concede that if the older figure is realistic, the SBH system almost certainly has been intermittently rather than continuously active for such a long span of time. In other words, the system has been repeatedly rejuvenated, either by influx of new magma batches, or through refaulting and refracturing during periods of particularly intense seismicity. Multiple episodes of hydrothermal activity are recorded in the SBH by: 1) Extinct hot-spring vents in portions of the field distant from current hot-spring discharge; 2) hydrothermal alteration antedating the Lousetown Andesite in some portions of the field, but clearly post-dating the Lousetown in other portions; and 3) extensive alteration zones suggesting long-duration discharge from some fault zones contrasted with trivial alteration haloes and implied short-term flow in producing fractures in the upper-tier thermal aquifer of the northeastern SBH. This evidence for long-term but episodic hydrothermal-fluid circulation at Steamboat could also indicate that structural controls have varied temporally and spatially throughout the field. It is within this context that we examine the potential roles of listric faulting, detachment faulting, and gravity sliding in the inception, expansion, and decline of multiple pulses of the SBH hydrothermal system over time.

\section{Fluid Distribution and Flat-Fracture Domain Theory for the SBH}

Our current work in the SBH is focused on evaluating the role of low-angle extensional tectonics and gravity sliding in the formation and control of the field's subhorizontal thermal aquifers. The work is part of a broader, EGS-oriented study with three principal objectives: (1) Realistically formulating new geothermal target types involving low-angle fracture domains; (2) evaluating and quantifying the means by which these domains preserve permeability even in the presence of (seemingly) unfavorably oriented stresses; and (3) predicting, in a general way (any mathematical modeling will be carried out under separate funding), the responses of buried gravity-slide blocks and lowangle fracture networks to artificial hydraulic stimulation for EGS. The SBH hydrothermal system was selected as a starting point for this investigation on the basis of the subhorizontal aquifers defined throughout the field and described briefly above (Figure 3; Sorey and Colvard, 1992; Mariner and Janik, 1995). Within the deeper, higher-temperature, SW portion of the SBH system, virtually all wells show major temperature reversals beneath high-temperature fluid entries. In the shallower, NE part of the system, all wells show temperature maxima at shallow depths within the productive interval, and minor to major temperature reversals or essentially isothermal temperatures beneath the production zones to total drilled depths.

The conceptual models utilized by field developers in formulating drilling targets for the SBH have traditionally featured the high-angle faults and fractures that arguably would be most likely to develop and maintain significant permeability in an extensional tectonic environment (e.g., Anderson, 1951; Hubbert and Willis, 1957). Such high-angle structures also fit nicely into conventional models of deep circulation as the main heat source for hydrothermal systems in the Basin and Range province (McKenna and Blackwell, 2004). SBH development drilling based on these high-angle-fault models has been indisputably successful in locating high-enthalpy fluids at depth, but as we have seen, the main thermal aquifers here are subhorizontal. With this aquifer geometry, no matter what the target model, vertical to gently-inclined production wells would seem to stand an excellent chance of success. Even so, the presence of flat-lying aquifers at Steamboat is somewhat at odds with classical stress-strain analysis, since flat fracture domains in this tectonic setting theoretically should be prone to closure once developed, and unlikely to undergo permeability rejuvenation. Nonetheless, subhorizontal fracture permeability at Steamboat remains a reality awaiting an explanation. Careful re-examination of existing SBH geologic data for possible evidence of low-angle structures is a key aspect of this study, along with scheduled, 1:4000-scale geologic and alteration mapping of the SBH, coupled with relogging of cores and cuttings from all available production and injection wells and cored slim holes. This report will summarize results of the investigation to date, and will document recent field observations bearing on the creation and geologic history of low-angle fracture domains within the geothermal field.

Low-angle thermal-fluid aquifers in the SBH geothermal system conceptually could have originated in a variety of ways. Among the possibilities we are considering:

- Progressive rotation of active, steeply-dipping normal faults to inactive, sub-horizontal configurations, as in the Yerington porphyry copper district $\sim 100 \mathrm{~km} \mathrm{SE}$ of Reno (Proffett, 1977).

- Large-scale gravity sliding, a common occurrence in highrelief, highly-extended terrain like the Basin and Range (e.g., Camilleri, 1992; French, 1993; Fryxell and Taylor, 1998). Depending upon the magnitude of gravitational drive, initial lithologic composition, and structural preparation of the affected rocks, this mechanism could cause rock rupturing ranging from widely spaced fractures to ultra-cataclastic "rock flour". An intermediate stage of development, with a penetrative network of "jigsaw-puzzle," centimeter to meter-scale fractures, theoretically would be most favorable for subsurface fluid flow in these features. 
- Listric normal faulting (e.g., Shelton, 1984), characterized by a decreasing angle of dip with depth. These features are common in the Roosevelt Hot Springs geothermal field (Nielson et al., 1986), where they are believed to have been instrumental in creating an essentially subhorizontal permeability network in the field's crystalline igneous and metamorphic rocks (Bruhn et al., 1982; Faulder, 1991).

- Detachment, attenuation, or denudation faulting (e.g., Armstrong, 1972; Rehrig, 1986; Spencer and Reynolds, 1989; Fryxell, 1991; Hardyman and Oldow, 1991; Axen et al., 1993; Flanigan, 1994; Fryxell and Taylor, 1998; and many others). This type of faulting, characterized by younger-over-older, low-angle displacements of considerable extent, can occur over a large depth range, from the brittle-ductile transition zone into fully brittle rocks much closer to the contemporaneous crustal surface (e.g., Gans et al., 1985; 1989; Fryxell, 1991). These features can clearly focus hydrothermal fluid flow. For example, Long (2004) has described, in preliminary fashion, a new class of ore deposit genetically affiliated with detachment faulting in the Miocene metamorphic core complexes of southwestern Arizona and southeasternmost California. The ores of this new deposit type occur, in part, in the gently-dipping detachments separating metamorphosed lower-plate rocks from non-metamorphosed upper-plate lithologies. In analogous fashion, probable regional attenuation faults between Devonian-Mississippian shales and carbonates in the eastern Great Basin focused Eocene ( $40 \mathrm{Ma})$ thermalfluid flow to form jasperoid blankets up to tens of meters thick and tens of $\mathrm{km}$ in areal extent (e.g., Hulen and Collister, 1999; Barton et al., 2000).

- Extensional re-activation of overthrust faults (e.g., Bartley and Gleason, 1990)

Whether in a natural-hydrothermal or EGS context, any of these flat-lying structures conceptually could serve as a major fluid channel. In the first case, the structures could provide first-order fluid entries; in the second, they could be targeted for connection to - and significant enlargement of - existing but nonproductive fracture networks by borehole-induced hydraulic rock rupture.

\section{Fluid Distribution and High-Angle Fracture Domains in the SBH}

Although the focus of this study is better definition of the roles of flat-fracture domains in hydrothermal systems, we do not lose sight of the fact that these subhorizontal features undoubtedly interact with high-angle faults and fractures more typical of the Carson Segment of the Walker Lane (recall, too, that high-angle faults are either exposed or inferred throughout the $\mathrm{SBH})$. While production horizons and major fluid flow in the explored SBH hydrothermal system are, as we have seen, essentially flat-lying phenomena, it is almost certain that these features are tied to one or more major hot upflow zones formed in response to the "deep-circulation" mechanism for hydrothermal heating (McKenna and Blackwell, 2004). Moreover, high-angle faults are the ones most likely to penetrate to sufficient depths to effect such deep heating. Remaining to be determined: whether the fracturing is somehow kinematically linked to the low-angle faulting, or is an essentially independent phenomenon.

Certainly, low-angle faulting linked to high-angle faulting has played a major role in channeling thermal-fluid flow in geologic settings in many ways analogous to the $\mathrm{SBH}$. As a particularly relevant example, Berger et al. (2003) have shown that the bulk of the orebodies in the historical Comstock lode, a few $\mathrm{km}$ east of Steamboat, formed in a major, northerlytrending, normal fault zone dipping in general only $30-35^{\circ}$ eastward over its entire $20-\mathrm{km}$ length. These workers go on to speculate that the ore-bearing fault flattens further with depth, ultimately to become a limited-displacement, subhorizontal detachment between and kinematically related to two subparallel, NW-trending, high-angle strike-slip to oblique-slip faults of the type commonly found in the Carson Segment of the Walker Lane belt.

The hydrothermal system that circulated during the formation of the main Comstock ores - that is, along the aforementioned shallow-dipping major fault - based on fluidinclusion homogenization temperatures would have circulated in the temperature range $200-300^{\circ} \mathrm{C}$ (Hayba et al., 1986) and would clearly have supported a world-class, electrical-grade, high-temperature geothermal field.

On a district scale, the features that we observe at SBH may be a variation of a model proposed by Gans (2005). According to this formulation, elevated pore-fluid pressures and low differential stresses in a thin brittle crust can result in localized extension-fracturing followed by rapid fault-block rotation. Closely-spaced normal faults begin as near-vertical tensile fractures, and then rotate very rapidly to low angles during progressive extension. These conditions may be due to the presence of shallow magma chambers in an extensional environment. In the $\mathrm{SBH}$, an obvious candidate for such a chamber would be the one from which the Pleistocene Steamboat rhyolite domes were sourced.

\section{Observations from this Study}

As specified by the terms of our agreement with DOE, this first year of the investigation we have: (1) assembled and analyzed pertinent published and proprietary material on low-angle faulting in general and low-angle-fault-controlled fluid flow in particular; (2) examined and analyzed (in unprecedented detail) drill cuttings from recent deep (up to $1830 \mathrm{~m}$ ) production wells in the southwestern, higher-temperature portion of the SBH geothermal system; and (3) conducted, with the new model in mind, a reconnaissance of outcrops, subcrops, and newly-excavated major fresh rock exposures throughout the area. By mid-September 2005, we will also have completed much of a new 1:4000-scale geologic map of the SBH, to be accomplished by combining traditional mapping methods with state-of-the-art remote-sensing and GIS technology.

Sinter Hill Area - In early 2005, cuts up to $15 \mathrm{~m}$ high and/or deep were made at the margin of the Sinter Hill sinter terrace (Figure 1). The spectacular exposures in these cuts consist almost entirely of massive chalcedonic sinter with 


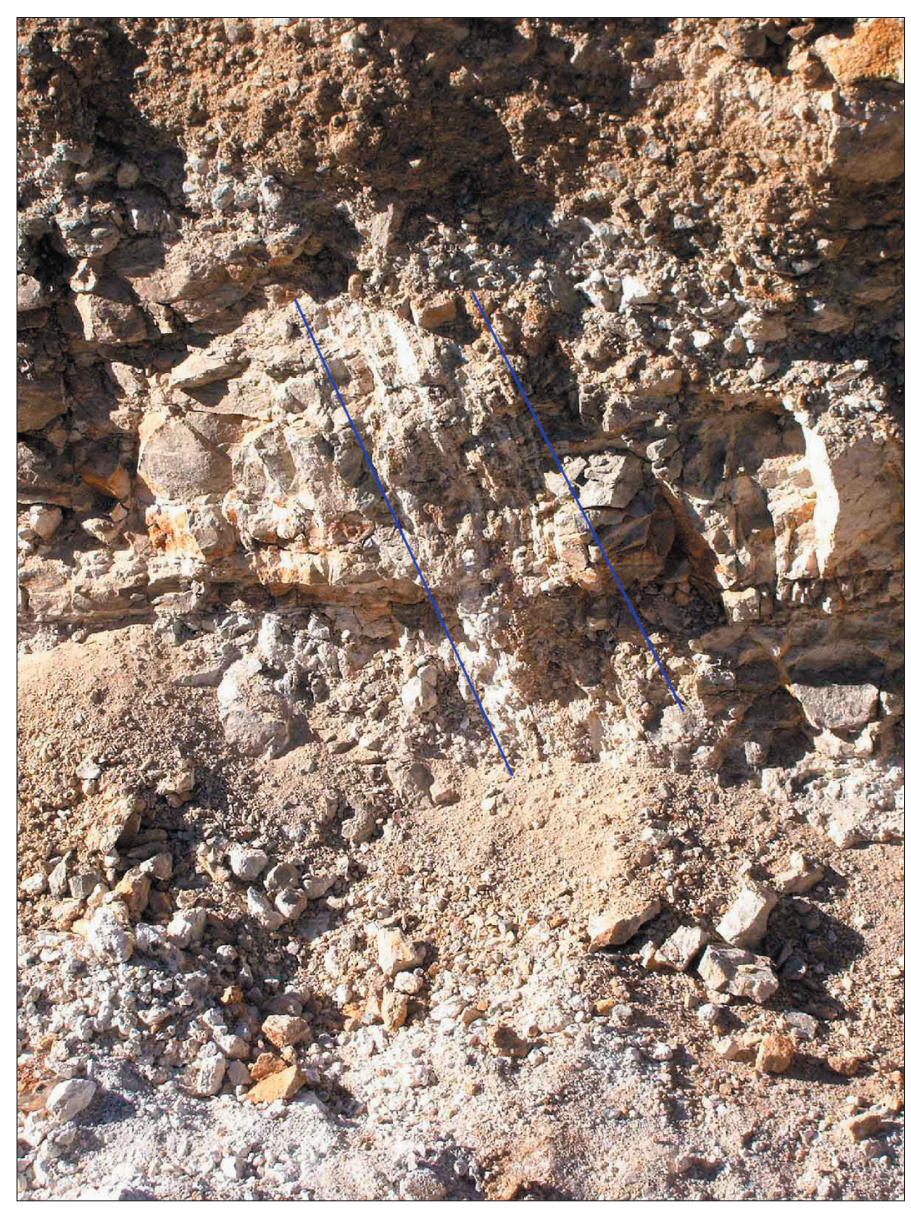

Figure 4. Steeply dipping silica vein system cutting chalcedony sinter in the Sinter Hill area. Vein is terminated by alluvial unconformity. Note lack of off-set in chalcedony sinter beds. Vein width is 30 centimeters.

trace amounts of cinnabar, metacinnabar and limonite (earthy iron oxide). A number of fossil feeder vents in the sinter were exposed and mapped as silica-filled minor faults/veins striking $\mathrm{N} 35-45^{\circ} \mathrm{W}$ (Figure 4, overleaf). The faults/veins, up to $25 \mathrm{~cm}$ thick, show only minor (a few $\mathrm{mm}$ ) vertical displacement of the disrupted, gently-inclined sinter beds; nonetheless, gouge is commonly observed along vein margins. The vein fillings (Figure 4) are banded silica alternating in color from white to dark gray. Individual color bands are in the thickness range $2-12 \mathrm{~mm}$, and the banding is symmetrically duplicated on either side of the vein axes.

These sub-sinter veins also branch horizontally, with the branches extending a meter or so, more or less concordantly, into the bedded sinter host rocks. Some of the veins are cut and terminated along bedding-plane shears in the chalcedony. The SW margin of the newly-exposed chalcedonic sinter is in fault contact with a silicified and iron-stained diatomite unit. Although relative fault motion here is uncertain, it appears likely that the diatomite is a younger unit in the hanging wall of a steeply dipping normal fault. Together, these features suggest past dynamic, fault-controlled fluid flow at Sinter Hill, as opposed to quiescent upflow along minor fissure zones in the sinter. The textures and orientations of the veins and associated tension gashes suggest that these features may have formed in response to oblique displacement along the NE fault trend that localized the Sinter Hill spring deposits. This style of faulting could also have developed localized basins for the accumulation of diatomite in proximity to the sinter deposits.

Drilling to set a conductor at this location encountered a massive glassy andesite unit beneath the chalcedonic sinter. Similar rocks are exposed in a highway cut several hundred feet to the west. In both cases, the glassy andesite contacts a dark-colored porcellanite that grades upward into the overlying chalcedony. While the andesite exposures in this general portion of the SBH have been considered as Lousetown Andesite (Figures 1 and 2), the glassy nature of the freshly revealed andesite is not characteristic of Lousetown flows near their vent areas $1.5 \mathrm{~km}$ to the SW. The glassy texture suggests that a volcanic vent contemporaneous with the early-formed sinters of Sinter hill may exist in this portion of $\mathrm{SBH}$.

Deeper drilling at this same location encountered relatively fresh granodiorite beneath the thin andesite sequence that included glassy tuffs. Significant permeability was found at a depth of $203 \mathrm{~m}$ in this well, and corresponding EMI (Halliburton Electrical Micro Imaging) logs define a low-angle fault zone dipping only about $20^{\circ}$. This flat-domain permeability zone sharply contrasts with the near-vertical faulting observed at the surface in this location. As with most production wells drilled in the $\mathrm{SBH}$, this well shows a sharp temperature drop - in this case about $16^{\circ} \mathrm{C}$ - between the base of the production zone and the bottom of the borehole a few tens of meters deeper. As our field work progresses, we will pursue a better understanding of such low-angle production faults within the context of the local geology.

Low-Angle Faulting - Within the SBH, low-angle faulting is hypothesized to occur at scales ranging from outcrop to potentially as large as an enormous gravity-slide block that displaced the SBH to the east - either en masse or in multiple blocks - from the seismically active Sierra Nevada range-front fault zone. While preliminary field observations have revealed widespread zones of cataclasis, rubblization, and jigsaw-puzzle shattering consistent with large-scale gravity sliding, detailed mapping and additional study will be required to verify this relationship. Similarly, examination of drill cuttings from deep production wells in the southwestern, higher-temperature part of the SBH has revealed well-defined shear zones, deep in Mesozoic bedrock, that appear to incorporate slickensided fragments of Tertiary volcanic rocks and sediments. These observations are also consistent with large-scale, low-angle faulting, but additional work is required for rigorous confirmation of the key observations.

On a more intimate scale, smaller gravity-slide blocks and landslides are associated with a number of mapped fault systems within the SBH. These features have lengths at the surface typically in the 200-m range, although some are smaller, and one in Pleasant Valley (Figure 1) is about $500 \mathrm{~m}$ long. The thicknesses of the slide blocks appear in general to be about half the strike lengths. Many of these slides are associated with young hydrothermal alteration. We have not yet determined if the alteration facilitated mass movement, or if the sliding led to enhanced hydrothermal activity. Several examples of slide block/thermal activity in the SBH are described and il- 


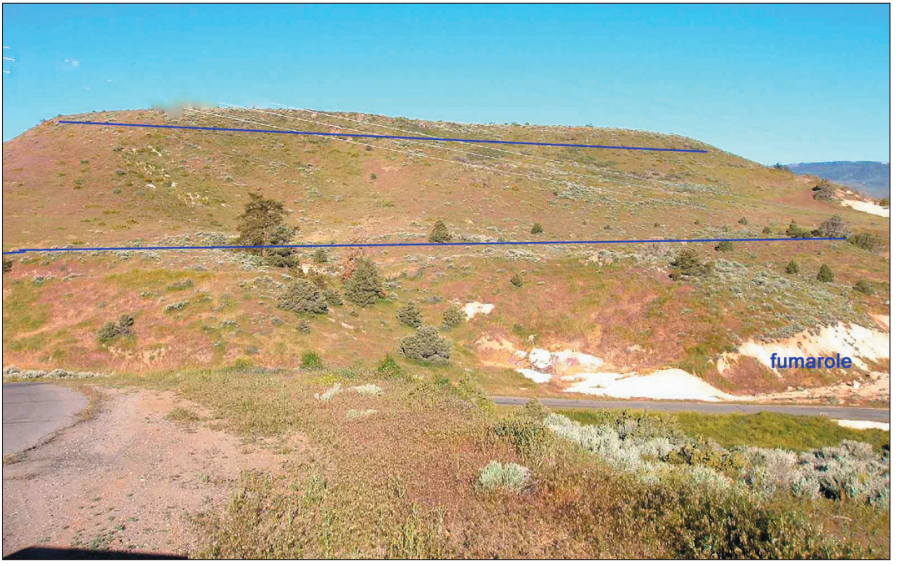

Figure 5. Mercury slide. Upper line indicates base of Lousetown andesite at top of fault scarp. Lower line is on top of Lousetown andesite in slide block. Area at lower right is highly altered granodiorite with fumarole activity and mercury/sulfur deposition.

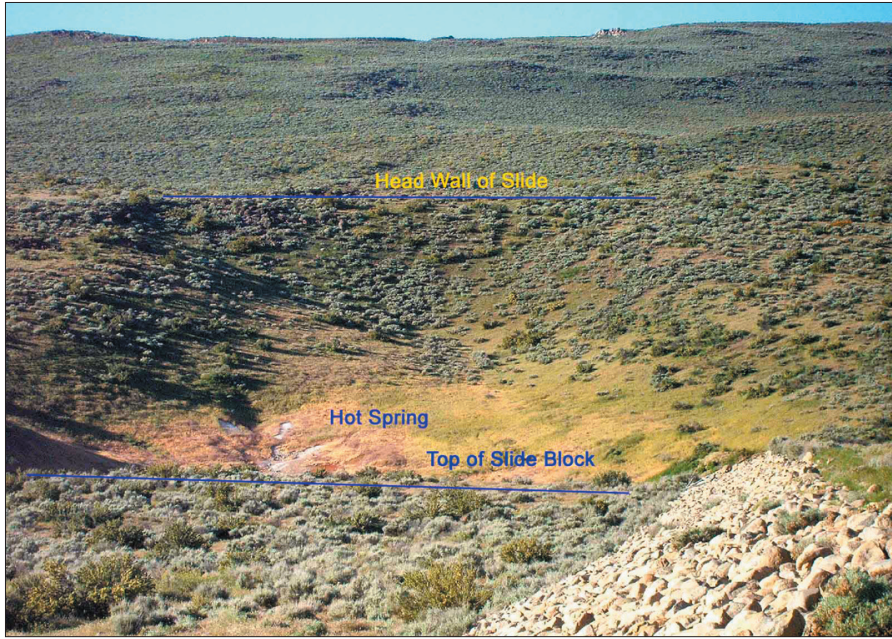

Figure 6. Galena slide. Headwall of slide is indicated in Lousetown andesite. Top of slide block in foreground. Hot spring issues from highly altered granodiorite.

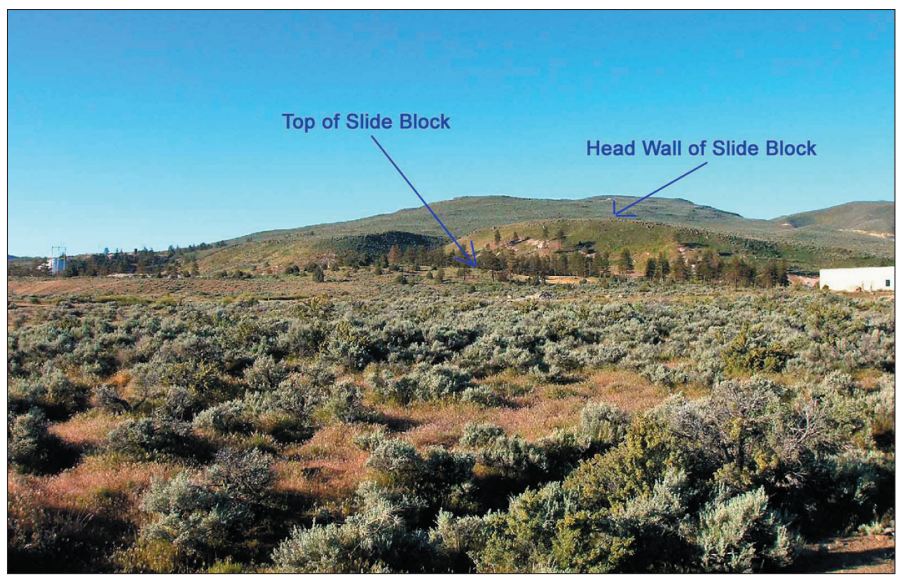

Figure 7. Nevada-Thermal slide block. Headwall of slide block in Lousetown andesite is indicated by arrow. Headwall block is rotated approximately $20^{\circ}$ on probable listric fault at depth. Slide block in foreground is highly altered Lousetown andesite with ongoing fumarole activity. lustrated as follows:

- Mercury slide block (Figure 5). Dimensions 300 x 100 m. Unaltered Lousetown Andesite at headwall of slide. Intensely altered granodiorite and fumarolic activity in the slide block itself.

- Galena slide block (Figure 6). Dimensions 100 x 100 m. Unaltered Lousetown Andesite at headwall of slide. Intensely altered granodiorite with an associated active hot spring and fumarole exposed in slide footwall.

- Nevada Thermal slide block (Figure 7). Dimensions poorly defined, perhaps 150 x 100 m. Unaltered Lousetown Andesite at headwall of slide. Intensely altered Lousetown along with fumaroles in poorly-exposed hanging-wall block.

- Flash-Plant slide block. Dimensions 300 x 200 m (Figure 8). Unaltered Lousetown Andesite and Mesozoic

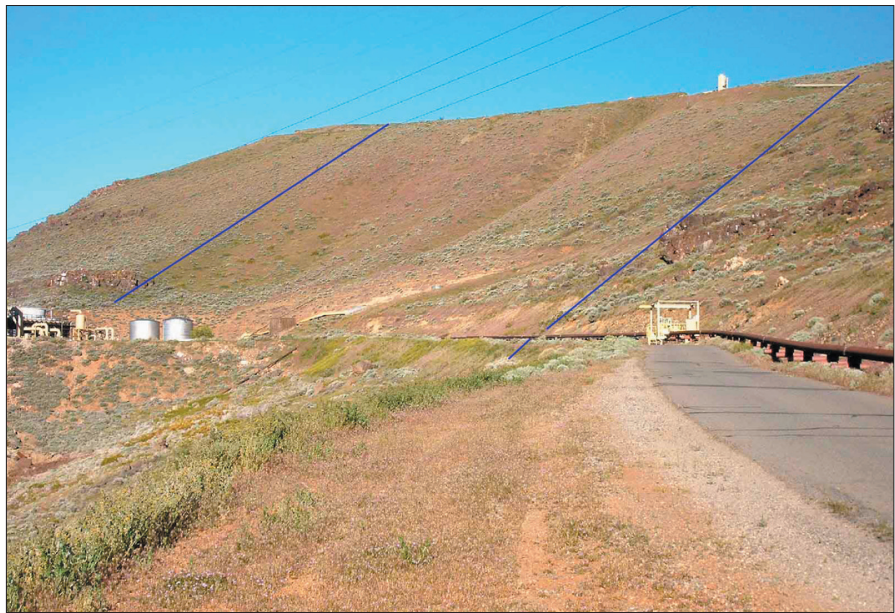

Figure 8. Plant slide. Lines indicate margins of slide block. Note the missing sliver of Lousetown andesite previously down-dropped by rangefront high-angle fault.

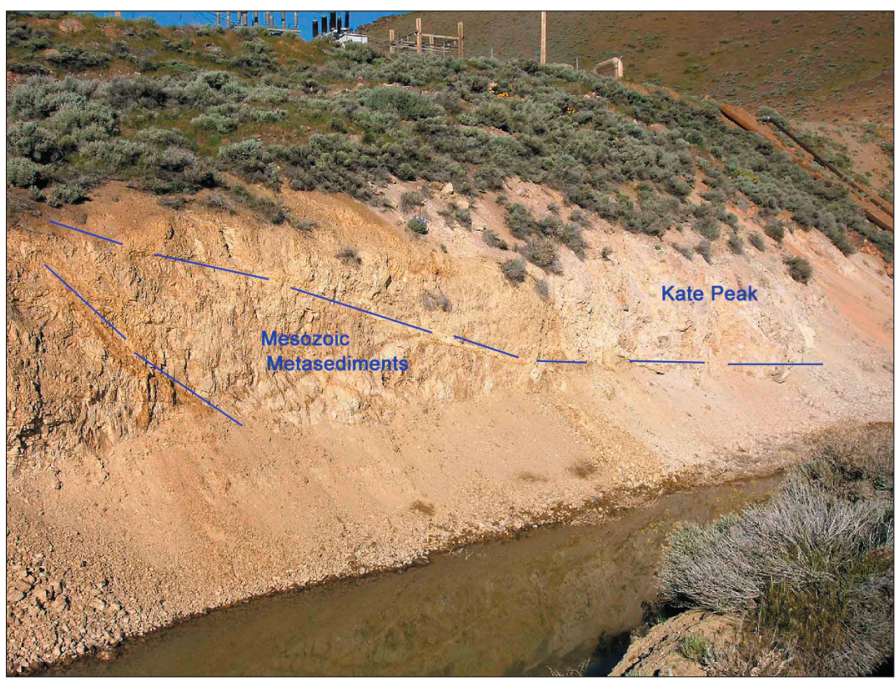

Figure 9. Plant slide block. Note low-angle fault that cuts both Kate Peak volcanics and Mesozoic sediments. Kate Peak volcanics are incorporated in fault gouge within the Mesozoic metasediments. 


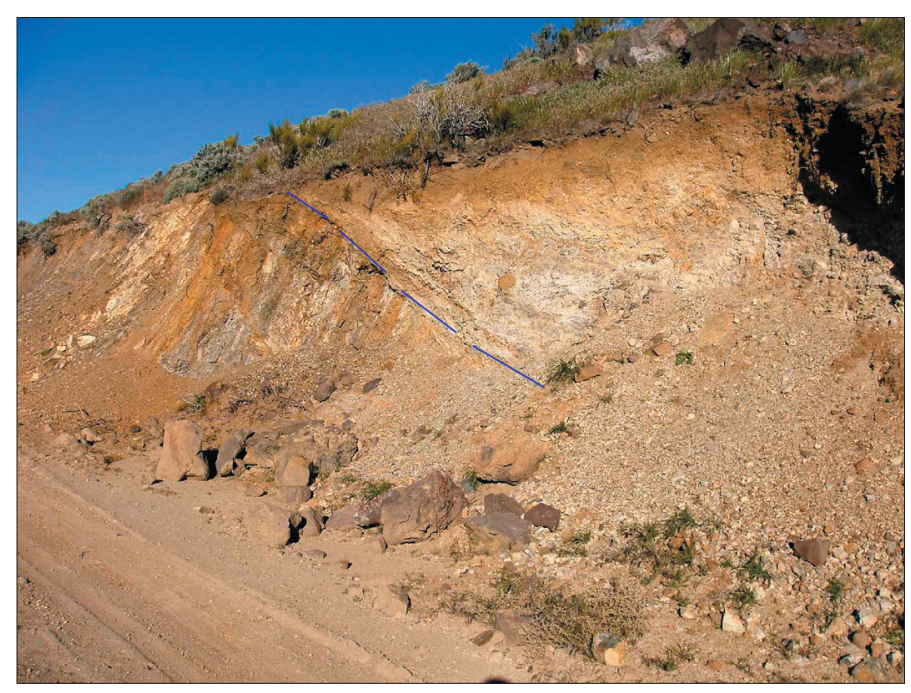

Figure 10. Low-angle shear zone in Mesozoic sediments at the head wall of the Plant slide. Dip on fault zone is approximately $20^{\circ}$.

metasedimentary rocks at headwall of slide. Footwall block shows low-angle faulting with Miocene Kate Peak rocks tectonically incorporated in the Mesozoic section (Figure 9). This zone overlies the hottest bottom-hole locations drilled to date at SBH. Low-angle faulting is also present in the Mesozoic metasedimentary section near the headwall of this slide block (Figure 10, overleaf).

- Pleasant Valley slide blocks. Dimensions 500 x $250 \mathrm{~m}$. Compound faults with some listric rotation. Extinct hot springs with siliceous sinter in hanging-wall block.

On a district-wide scale, our observations and findings relative to low-angle faulting are preliminary, as the requisite detailed mapping has not been conducted. However, the fact that large blocks of Mesozoic metasediments are shattered and show minor-scale low-angle structures is suggestive of flat-domain tectonics.

\section{Conclusions}

Our observations to date confirm that, at least on a local scale, gravity-slide-block faults enhance local hydrothermal activity at and near the surface in areas of the SBH affected by faulting. These faults appear to be listric, and to have undergone some rotation of hanging-wall blocks. On a district scale, our limited observations, although permissive of large-scale lowangle faulting, are not yet sufficient to demonstrate the presence of thermal-fluid-flow-controlling, flat-fracture domains. During the 2005 field season (in August), we will initiate and complete much of the detailed field mapping scheduled as a key component of this project. We will also have available, in support of the work, drill cuttings and wellbore geophysical data (in particular, EMI) for several new production wells sited in areas where we strongly suspect the concealed subsurface presence of low-angle structures as major thermohydrologic elements of the SBH system. Drilling in the Sinter Hill area may provide additional insight into the nature of the newly-revealed, glassy andesitic volcanics as well as fault systematics in the SW sector of the edifice. The glassy andesite recently discovered beneath the Sinter Hill sinter is decidedly non-characteristic of the 2.5 Ma Lousetown Andesite flows andesites vented $1.5 \mathrm{~km}$ south of this area, possibly indicating that the glassy andesite is a younger volcanic erupted from a previously unknown local source.

\section{Acknowledgements}

This work is being supported by: 1) the U.S. Department of Energy, Office of Geothermal Technologies, under the auspices of Grant No. DE-FG36-04GO14296; and 2) ORMAT Nevada, Inc. The authors appreciate this support, and additionally wish to thank ORMAT for access to the study area; for generous in-kind contribution in the form of wellbore geophysical data and drill cuttings; and for permission to publish this paper.

\section{References}

Anderson, E.M., 1951, The dynamics of faulting: Edinburgh, Oliver and Boyd, $206 \mathrm{p}$.

Armstrong, R.L., 1972, Low-angle (denudation) faults, hinterland of the Sevier orogenic belt: Geological Society of America Bulletin, v. 98 , p. $308-319$.

Axen, G.J., Taylor, W.T., and Bartley, J.M., 1993, Space-time patterns and tectonic controls of Tertiary extension and magmatism in the Great Basin of the western United States: Geological Society of America Bulletin, v. 105, p. 56-76.

Bartley, J.M., and Gleason, G., 1990, Tertiary normal faults superimposed on Mesozoic thrusts, Quinn Canyon and Grant Ranges, Nye County, Nevada, in Basin and Range extensional tectonics near the latitude of Las Vegas, Nevada: Geological Society of America, Memoir 176 , p. $195-212$.

Barton, M.D., Seedorf, E., Ilchik, R.P., and Ghidotti, G., 1997, Contrasting siliceous replacement mineralization, east-central Nevada, in Carlin-type gold deposits field conference (P. Vikre, T. Thompson, K. Bettles, O. Christensen, and R. Parrat, eds.): Society of Economic Geologists, Guidebook Series, v. 28, p. 131-136.

Berger, B.R., Tingey, J.V., and Drew, L.J., 2003, Structural localization and origin of compartmentalized fluid flow, Comstock Lode, Virginia City, Nevada: Economic Geology, v. 98, p. 387-408.

Bruhn, R.L., Yusas, M.R., and Huertas, F., 1992, Mechanics of low-angle faulting - an example from Roosevelt Hot Springs geothermal area: Tectonophysics, v. 86, p. 343-361.

Camilleri, P.A., 1992, Extensional geometry of a part of the northwestern flank of the northern Grant Range, Nevada - Inferences on its evolution: Denver, The Mountain Geologist, v. 29, p. 75-84.

Castor, S.B., Garside, L.J., Henry, C.D., Hudson, D.M., MacIntosh, W.C., and Vikre, P.G., 2002, Multiple episodes of magmatism and mineralization in the Comstock district, Nevada: Geological Society of America Abstracts with Programs, v. 34, p. 185.

DeRocher, T., 1996, Historical summary of Caithness Power, Inc., hydrologic monitoring of the Steamboat Hills region, 1987-present: Yankee-Caithness Joint Venture, Draft Report, 46 p.

Faulder, D.D., 1991, Conceptual geologic model and native state model of the Roosevelt Hot Springs hydrothermal system: Stanford University, $16^{\text {th }}$ Workshop on Geothermal Reservoir Engineering, Report SGP-TR-134, p. 131-142.

Flanigan, T., 1994, Blackburn field - Oil above a low-angle detachment fault in Eureka County, Nevada, in Oil fields of the Great Basin (R.A. Schalla and E.H. Johnson, eds.): Reno, Nevada Petroleum Society, p. 343-364. 
Flynn, T., Buchanan, P.K., and Miller, J.D., 1993, Core lithology and photographs, slim hole SNLG 87-29, Steamboat Hills, Nevada: University of Nevada (Las Vegas), Harry Reid Center for Environmental Studies and Marjorie Barrick Museum of Natural History, 20 p. (with numerous illustrations and appendices).

French, D.E., 1993, Debris slides of the Railroad Valley area, Nye County, Nevada - Yet another interpretation of Grant Canyon and Bacon Flat fields (abs.): American Association of Petroleum Geology Bulletin, v. 77, p. 1448.

Fryxell, J.E., 1991, Tertiary tectonic denudation of an igneous and metamorphic complex, west-central Grant Range, Nye County, Nevada, in Geology and ore deposits of the Great Basin (G.L. Raines, R.E. Lisle, R.W. Schafer, and W.H. Wilkinson, eds.): Reno, Geological Society of Nevada, Symposium 1990, p. 87.

Fryxell, J.E., and Taylor, W.J., 1998, East-west structures, detachment faults, and megabreccias of the Railroad Valley area, in Hydrocarbon habitat and special geologic problems of the Great Basin (D.E. French and R.A. Schalla, eds.): Reno, Nevada Petroleum Society, 1998 Field Trip Guidebook, p. 54-55.

Gans, P.B., Miller, E.L., McCarthy, J., and Ouldcott, M.L., 1985, Tertiary extensional faulting and evolving brittle-ductile transition zones in the northern Snake Range and vicinity - New insights from seismic data: Geology, v. 13, p. 189-193.

Gans, P.B., Mahood, G.A., and Schermer, E., 1989, Synextensional magmatism in the Basin and Range province - A case study from the eastern Great Basin: Geological Society of America, Special Paper 233, $53 \mathrm{p}$

Gans, P.B., 2005, Geometry and Kinematics of Extensional Fault Systems, Abstract: http://www.geol.ucsb.edu/faculty/gans/abstracts/ geom.kin.html.

Hayba, D.O., Bethke, P.M., Heald, P., and Foley, N.K., 1986, The geological, mineralogical, and geochemical characteristics of volcanic-hosted epithermal deposits, in Geology and geochemistry of epithermal systems (B.R. Berger and P.M. Bethke, eds.): Society of Economic Geologists, Reviews in Economic Geology, v. 2, p. 129-168.

Hardyman, R.F., and Oldow, J.S., 1991, Tertiary tectonic framework and Cenozoic history of the central Walker Lane, Nevada, in Geology and ore deposits of the Great Basin (G.L. Raines, R.E. Lisle, R.W. Schafer, and W.H. Wilkinson, eds.): Reno, Geological Society of American, Symposium 1990, Proceedings, p. 279-301.

Hubbert, M.K., and Willis, D.G., 1957, Mechanics of hydraulic fracturing: American Institute of Mining, Metallurgy, and Petroleum Engineering, v. 210, p. 153-166.

Hulen, J.B., and Collister, J.W., 1999, The oil-bearing, Carlin-type gold deposits of Yankee basin, Alligator Ridge district, Nevada: Economic Geology, v. 94, p. 1029-1051.

Long, K.R., 2004, Preliminary Descriptive Deposit Model for Detachment-Fault Related mineralization, in Developments in Mineral Deposit Modeling, J. D. Bliss, editor: USGS Bulletin 2004, http://pubs. usgs.gov/bu/lb2004/.

Kennedy, B. M., van Soest, M. C., and Johnson, S., 2003, Helium Isotopes in Dixie Valley Wells, Springs and Fumaroles: Heat and Fluid Sources; Regional Trends, $28^{\text {th }}$ Stanford Geothermal Workshop, Abstract, http:// pangea.stanford.edu/PetEng/geoth/workshop28/kennedy.html.

Mariner, R.H., and Janik, C.J., 1995, Geochemical data and conceptual model for the Steamboat Hills geothermal system, Washoe County, Nevada: Geothermal Resources Council, Transactions, v. 19, p. 191-197.

McKenna, J.R., and Blackwell, D.D., 2004, Numerical modeling of Transient Basin and Range extensional geothermal systems, Geothermics, v. 33 , p. $457-476$.

Nathwani, J., and Creed, R.J., 2002, DOE's Enhanced Geothermal Systems program: Geothermal Resources Council, Transactions, v. 26, p. $235-236$.
Nielson, D.L., Evans, S.H., and Sibbett, B.S., 1986, Magmatic, structural, and hydrothermal evolution of the Mineral Mountains intrusive complex, Utah: Geological Society of America Bulletin, v. 97, p. 765-777.

Parsons, T., 1995, The Basin and Range province, in Continental rifts - Evolution, structure, and tectonics (K.H. Olsen, ed.): Amsterdam, Elsevier, 277-324.

Proffett, J.M., Jr., 1977, Cenozoic geology of the Yerington district, Nevada, and implications for the nature and origin of Basin and Range faulting: Geological Society of America Bulletin, v. 88, p. 247-266.

Rehrig, W.A., 1986, Processes of regional Tertiary extension in the western cordillera - Insights from the metamorphic core complexes, in Extensional tectonics of the southwestern United States - A perspective on processes and kinematics (L. Mayer, ed.): Geological Society of America, Special Paper 208, p. 97-122.

Schoen, R., and White, D.E., 1967, Hydrological alteration of basaltic andesite and other rocks in drill hole GS-6, Steamboat Springs, Nevada, in Geological Survey research, 1967: U.S. Geological Survey, Professional Paper 575-B, p. B110-B119.

Schoen, R.W., White, D.E., and Hemley, J.J., Argillization by descending acid at Steamboat Springs, Nevada: Clays and Clay Minerals, v. 22 , p. $1-22$.

Shelton, J.W., 1984, Listric normal faults - An illustrated summary: American Association of Petroleum Geologists Bulletin, v. 68, p. 801-815.

Silberman, M.L., White, D.E., Keith, T.E.C., and Dockter, R.D., 1979 , Duration of hydrothermal activity at Steamboat Springs, Nevada, from spatially associated volcanic rocks: U.S. Geological Survey Professional Paper 458-D, 64 p.

Sorey, M.L., and Colvard, E.M., 1992, Factors affecting the decline in hotspring activity in the Steamboat Springs area of critical environmental concern, Washoe County, Nevada: U.S. Geological Survey Administrative Report for the U.S. Bureau of Land Management, 109 p.

Spencer, J.E., and Reynolds, S.J., 1989, Tertiary structure, stratigraphy, and tectonics of the Buckskin Mountains, in Geology and mineral resources of the Buckskin and Rawhide Mountains, west-central Arizona (J.E. Spencer and S.J. Reynolds, eds.): Arizona Geological Society, Bulletin 198, p. 103-167.

Stewart, J.H., Tectonics of the Walker Lane belt, western Great Basin - Mesozoic and Cenozoic deformation in a zone of shear, in Metamorphism and crustal evolution of the western United States (Rubey Volume; W.G. Ernst, ed.): Englewood Cliffs, New Jersey, PrenticeHall, p. 668-713.

Stewart, J.H., 1999, Geologic map of the Carson City 30 x 60 minute quadrangle, Nevada: Nevada Bureau of Mines and Geology, Map 118, Scale 1:100,000.

van de Kamp, P.C., and Goranson, C.B., 1990, Summary of the hydrological characteristics of the Steamboat Hills area, Nevada: Consulting Report for Caithness Power, Inc., and Yankee-Caithness Joint Venture, $60 \mathrm{p}$.

Vikre, P.G., McKee, E.H., and Silberman, M.L., 1988, Chronology of Miocene hydrothermal and igneous events in the western Virginia Range, Washoe, Storey, and Lyon Counties, Nevada: Economic Geology, v. 83, p. 864-874.

White, D.E., 1968, Hydrology, activity, and heat flow of the Steamboat Springs thermal system, Washoe County, Nevada: U.S. Geological Survey, Professional Paper 458-C, 109 p.

White, D.E., Thompson, G.A., and Sandberg, C.H., 1964, Rocks, structure, and geologic history of the Steamboat Springs thermal area, Washoe County, Nevada: U.S. Geological Survey Professional Paper 458-B, $63 \mathrm{p}$. 


\title{
A Dual Hypothesis for Thermal-Fluid Advection in the Northern Steamboat Geothermal Field, Nevada-Upflow in Ancient Breccia Pipes; Distributed Outflow in a Low-Angle Extensional Fault Zone
}

\author{
Stuart D. Johnson ${ }^{1}$ and Jeffrey B. Hulen ${ }^{2}$ \\ ${ }^{1}$ ORMAT Nevada, Inc., Reno, NV \\ ${ }^{2}$ Energy \& Geoscience Institute, University of Utah, Salt Lake City, UT \\ sjohnson@ormat.com • jhulen@egi.utah.edu or jbh_rmh@comcast.com
}

\section{Keywords}

Steamboat Hills, Steamboat geothermal system, Nevada, Basin and Range province, thermal aquifers, low-angle extensional faulting, detachment faulting, "flat faults," listric faulting, fractures, stockworks, breccias, breccia bodies, breccia pipes, hydrothermal alteration, advanced argillic, intermediate argillic, phyllic, propylitic, silicification, veins, euhedral crystals, mineralization, porphyry $\mathrm{Cu}-\mathrm{Mo}$, chalcopyrite, molybdenite, magmatic-hydrothermal, thermal-fluid flow, advection, upflow, outflow

\section{ABSTRACT}

Results from drilling and geologic logging of six recently completed, shallow- to intermediate-depth wells in the northern Steamboat geothermal field strongly support the premise (Hulen and Johnson, 2004; Johnson and Hulen, 2005) that commercial thermal-fluid entries in this traditionally shallow $(<350 \mathrm{~m})$ part of the resource are controlled by an areally extensive, low-angle extensional fault zone. The new geologic data - when integrated with corresponding static temperature/ pressure logs and other borehole information-additionally suggest that this gently-inclined, fault-controlled thermal aquifer could be fed from greater depth by an upflow zone exploiting relict permeability in a $\mathrm{Cu}-\mathrm{Mo}$-mineralized, magmatichydrothermal breccia pipe of probable late Cretaceous age.

Key findings underpinning our new dual hypothesis for thermal-fluid advection at Steamboat can be summarized as follows: (1) As confirmed by each well, the reservoir rock in this part of the field is late Cretaceous Sierran granodiorite; (2) A moderate-temperature (that is, within the $150-180^{\circ} \mathrm{C}$ range) commercial thermal-fluid entry zone was encountered in all six wells (separated by up to $1.6 \mathrm{~km}$ ) at $\sim 1200 \mathrm{~m}$ elevation and within $\sim 350 \mathrm{~m}$ of the modern ground surface. This entry zone (one of lost-circulation when drilled) is typically but not invariably signaled at shallower depths by silicified cataclasite along with euhedral quartz crystals in epithermal veins and breccia cements; (3) Above the fluid-entry zone (but not systematically linked to it), the granodiorite in at least three of the wells hosts highly anomalous combined concentrations $(0.1-1.4 \%$ over 3-m depth intervals) of relatively coarse-crystalline (up to 3 $\mathrm{mm}$ ) molybdenite and chalcopyrite; (4) The one well drilled through the entry zone and deeper into the granodiorite encountered - as anticipated and below $540 \mathrm{~m}$ depth - the sole, spent-fluid injection zone for the entire developed southern sector of the Steamboat field. The injection zone is identified here, for the first time, as a highly porous, chalcopyrite- and molybdenite-bearing granodiorite breccia overprinted by drusy epithermal quartz. The breccia is texturally reminiscent of those found in Mesozoic to early Cenozoic, $\mathrm{Cu}$-Mo-mineralized breccia pipes at numerous locations along the North and South American cordillera. Many of these ancient pipes have surprisingly sizable relict porosities, and if placed conceptually in a modern geothermal system would certainly channel (or store) correspondingly high thermal-fluid volumes: This may be the actual scenario at Steamboat.

The occurrence of Steamboat's shallow productive permeability in a crystalline igneous host rock at essentially the same elevation in six wells up to $1.6 \mathrm{~km}$ apart - not to mention repetition of this occurrence in previously-drilled wells-is beyond the realm of coincidence. We contend that this now well-confirmed phenomenon (1) provides nearly unequivocal evidence that the producing horizon here is a major low-angle fault zone; and (2) enhances the odds that similar structures will emerge as important reservoir controls in numerous geothermal systems known and yet to be found throughout the Basin and Range province.

It seems clear that our evolving model of the Steamboat geothermal system must now take into account not only these "flat" thermal aquifers, but also the possibility that deeper thermal fluids here may travel opportunistically in ancient breccia pipes. The (now) more steeply-inclined of these pipes, "beheaded" by permeable low-angle faults, could channel modern hot-water upflow into these structural aquifers for broad distribution throughout the Steamboat resource. As displacements on the low-angle faults are unknown, the locations of the breccia-pipe "heads" are equally conjectural. We 


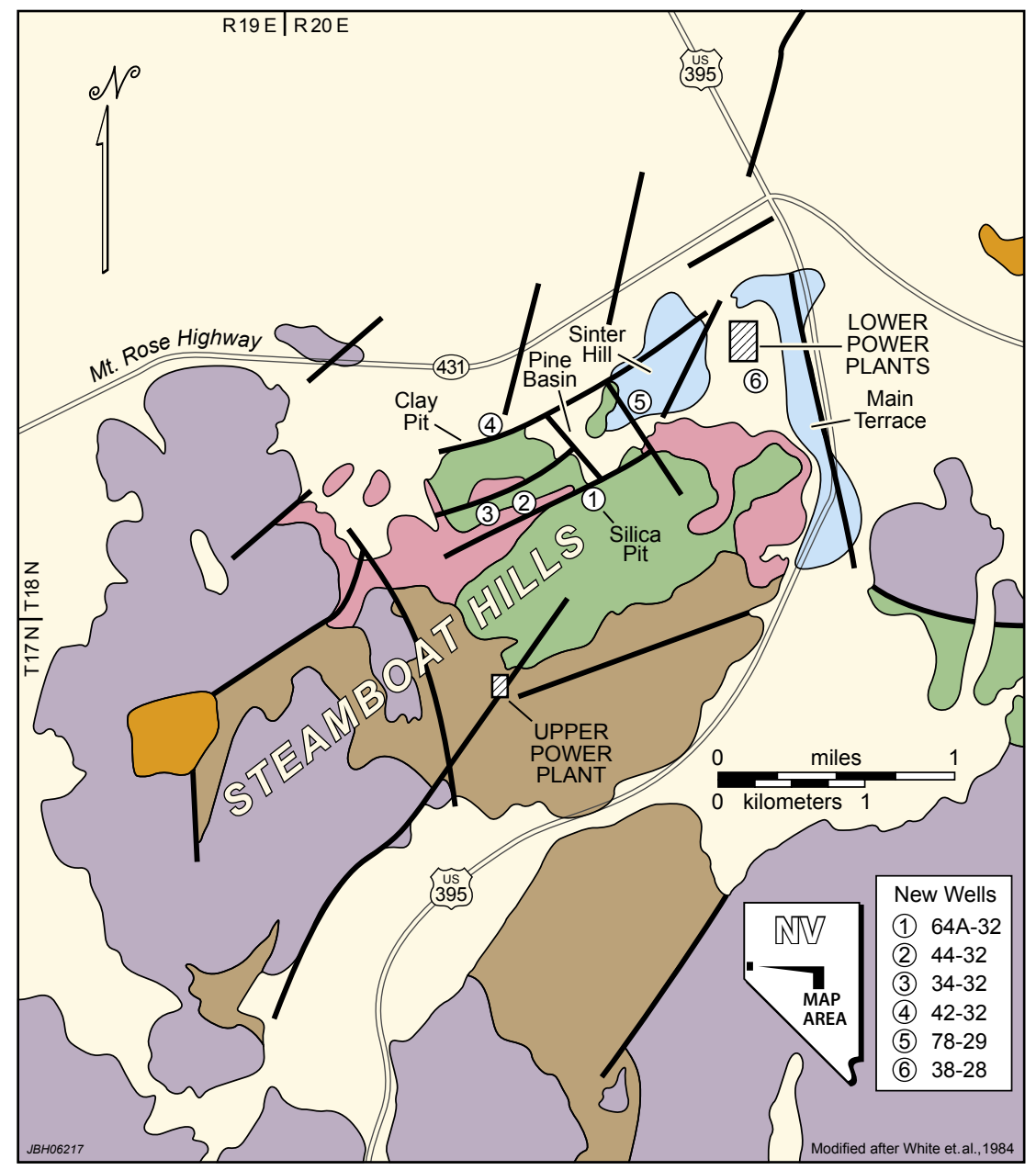

HIGH-ANGLE FAULT

QUATERNARY SURFICIAL DEPOSITS QUATERNARY SILICEOUS SINTER QUATERNARY STEAMBOAT RHYOLITE PLIOCENE LOUSETOWN BASALTIC ANDESITE

Figure 1. Highly simplified location and geologic map of the Steamboat Hills, showing approximate positions of recently completed geothermal wells and other features discussed in the accompanying text.

speculate that the latter features would have been ideal foci for Steamboat's well known Quaternary phreatic explosions.

\section{Introduction}

Five production wells (34-32, 38-28, 42-32, 44-32, and 7829; Figure 1) and a replacement injection well (64A-32; Figure 1) have been completed recently by ORMAT Nevada, Inc., in the Steamboat geothermal field. All six wells are commercial successes. $78-29$ now supplies $\sim 170^{\circ} \mathrm{C}$ reservoir fluid to the new $20 \mathrm{MW}_{\mathrm{e}}$, Richard Burdette (Galena I) power plant. 64A-32 has supplanted aging adjacent injector Cox I-1 (not illustrated). The other new production wells will provide thermal fluid to the planned Galena II power plant, and perhaps, along with additional wells yet to be drilled, an envisioned Galena III facility.
From a basic research perspective (not entirely detached from the commercial view), the six study wells have provided valuable new insight into the Steamboat field's hitherto cryptic reservoir controls. We are in the second year of a multidisciplinary research investigation, sponsored jointly by the Department of Energy (DOE; Office of Geothermal Technologies) and ORMAT, aimed at better understanding (1) the nature and significance of low-angle fractures and fracture domains in natural hydrothermal systems of the western United States; and (2) the bearing of such structures on exploration for and development of Enhanced Geothermal Systems (EGS), widely believed to be "the future for power from the Earth" (e.g., Nathwani and Creed, 2002).

Low-angle faults and fractures could be among the more important thermohydrologic elements in western U.S. geothermal systems. The proposed (Hulen et al., 2004; Johnson and Hulen, 2005) premier example of control by these features on thermal-fluid flow is the Steamboat geothermal field (Figure 1), located in the Steamboat Hills, about $20 \mathrm{~km}$ south-southeast of Reno, Nevada. The Steamboat system is hosted principally by Mesozoic metamorphic and crystalline igneous rock, yet its productive thermal aquifers are demonstrably subhorizontal (e.g., Mariner and Janik, 1995; DeRocher, 1996). In an earlier report on this phenomenon (Johnson and Hulen, 2005), we (1) extended our investigation of the nature and origin of such "flat-fracture" domains through detailed geologic mapping and field observation in the western Steamboat Hills; and (2) described exposures of actual and likely gravity-slide blocks in the Hills, particularly as these outcrops might relate to the configuration of major thermal-fluid channels at depth.

The five new production wells studied in detail for this phase of our investigation penetrated fracture systems typical of the northern, traditionally shallower, portion of the Steamboat resource beneath (1) the "Clay Pit" (Figure 1); (2) the basaltic andesitecovered gentle northeastern slopes of the Steamboat Hills; (3) the western portion of Pine Basin; (4) Sinter Hill, a largely chalcedonic sinter mound; and (5) the area between Sinter Hill and the "Main (sinter) Terrace". The deeper injection well, near the "Silica Pit" (Figure 1), encountered not only the shallow thermal aquifer, but also a deeper high-permeability zone utilized for years in now-abandoned Cox I-1 to inject the bulk of the southern Steamboat field's spent production fluids. New geologic data and insight from the six new wells has led to significant revision of our conceptual model of the geologic framework and tectonic-magmatic-hydrothermal history of the Steamboat geothermal system; and of the subsurface permeability architecture controlling the system's consistently productive, moderate- to high-temperature thermal-fluid flow. 


\section{Regional Geologic Setting}

The Steamboat Hills (Figure 1) comprise an east-northeast-oriented group of low-relief, rounded, and conspicuously hummocky hills just east of and slightly separated from the steep eastern range front of the Sierra Nevada (here called the Carson Range). The Hills are part of the Carson Segment of the Walker Lane (Stewart, 1988), at this latitude a structurally intricate, $\sim 100 \mathrm{~km}$-wide belt separating the Sierra Nevada microplate from the "typical" Basin and Range to the east (e.g., Parsons, 1995). The Carson Segment is characterized by northeast-trending, high-angle, left-lateral, strike-slip to oblique-slip faults. These structures are believed to facilitate displacement transfer between the northerly-trending, obliqueslip faults at the Sierra Nevada range front and the northwesttrending strike-slip faults that are the signature features of the Walker Lane as a whole.

The oldest rocks exposed within the Carson Segment are Late Triassic to Jurassic metasiliciclastic and metavolcanic rocks (Stewart, 1999), intruded extensively by Jurassic to Cretaceous stocks, plugs, and dikes ranging in composition from diorite to granite, and emplaced as satellitic plutons flanking the giant composite Sierra Nevada batholith. These older rocks are overlain unconformably by the medial to distal portions of regionally extensive, Oligocene to early Miocene, felsic ignimbrite sheets erupted from caldera sources farther inland to the east and southeast. Overlying the erosionally dissected ash-flow tuffs are andesitic to dacitic flows and flow breccias and minor lacustrine sedimentary rocks of the Miocene (18$15 \mathrm{Ma}$ ) Alta Formation (Castor et al., 2002). Alta-volcanic intrusive equivalents - plutons including the Davidson diorite in the nearby Comstock mining district - are locally exposed throughout the region. The Alta Formation is overlain by a second, similar, major intermediate-composition volcanic sequence, the Miocene (15-12 Ma) Kate Peak Formation (Vikre et al., 1988; Castor et al., 2002). Younger volcanic units throughout the Carson Segment are much more local in distribution, and range in composition from basalt to rhyolite. Representatives of this younger volcanic group found in the Steamboat Hills are discussed later in this report.

\section{Geology and Thermohydrology of the Steamboat Hills and Vicinity}

Note-This section differs little from its counterpart in Johnson and Hulen (2005). It is updated from the earlier manuscript, but is included here mainly for clarity and context, and so that the present paper can serve as a "stand-alone" document for ensuing investigation of the Steamboat geothermal system.

The geology of the Steamboat Hills (Figure 1) has been described in detail by White et al. (1964) and White (1968), classic papers that provide the basis for the following synopsis and discussion.

\section{Lithology}

Mesozoic (probably Triassic) siliciclastic to calcareous metasedimentary rocks and minor intermediate-composition metavolcanic rocks exposed widely in the southeastern half of the Steamboat Hills (Figure 1) are intruded by a composite stock consisting of at least three phases of hornblende- and/or biotite-bearing Sierran granitoid of probable late Cretaceous age (Flynn et al., 1993). These rocks are overlain locally in the study area by andesitic flows, flow breccias, and lahars assigned both to the Alta and Kate Peak Formations (Figure 1). The 2.2-2.5 Ma Lousetown Basaltic Andesite unconformably overlies both formations, and includes olivine basalt flows as well as pyroxene andesite. Lousetown cinder cones mark vent locations at the crest of the Hills. The Steamboat Hills are coaxial with a chain of 1.12-1.52 Ma rhyolitic volcanic centers (Silberman et al., 1979) extending from near the western edge of the knolls (Figure 1) to a point about 15 kilometers to the east-northeast. The 1.12-1.15 Ma rhyolite dome in the western Steamboat Hills is too old to be the intrusive equivalent of a felsic magma chamber still providing heat for the active geothermal system. However, this chamber could readily have heated a prior manifestation of the system in the nottoo-distant past.

All of the above units are blanketed locally by Pleistocene to Holocene surficial deposits, including fan and stream gravels, glacial outwash, and lacustrine sediments. Gravels near the sinter deposits are opal-cemented. Phreatic-explosion lithic tuffs are found within and adjacent to the northern Steamboat Hills, and are likely present above the granitic basement in several of the geothermal wells studied for this phase of our investigation.

\section{Late Pliocene to Holocene Hot-Spring and Phreatic-Eruption Deposits}

The Steamboat geothermal field is famous for its siliceous sinter mounds and notable for its phreatic-eruption deposits (e.g., White et al., 1964). The sinters, about a square kilometer in aggregate areal extent, range from wholly chalcedonic varieties likely pre-dating the Lousetown Basaltic Andesite, to entirely opaline types considered to be mid-Pleistocene to Holocene in age. Radiocarbon dating of pollen and plant fragments in opaline sinter penetrated by a northern Steamboat corehole yielded ages ranging from $6.3 \mathrm{ka}$ to $11.5 \mathrm{ka}$ (Lynne et al., 2003). The thickest Steamboat sinter accumulations clearly mark major long-lived hydrothermal discharge zones.

Quaternary phreatic-eruption craters and associated lithicpyroclastic debris have been documented unambiguously at the northern edge of the Steamboat Hills (White et al., 1964), and have long been suspected by ORMAT geoscientists to occur locally and more cryptically elsewhere in the field. Later in this report, we will discuss "sandstones," in some of the new production and injection wells, that are much more likely to be texturally equivalent phreatic-explosion tuffs and corresponding, subterranean microbreccias.

\section{Structure}

High-angle faults mapped or inferred from photolinears in the mostly "float" (colluvium; talus; skree)-covered Steamboat Hills are of three principal orientations - northeast, northwest, and northerly (White et al., 1964). The northwest- and northeast-trending faults mirror, respectively: (1) the right-lateral, strike-slip, principal displacement zones of the Carson Segment 
of the Walker Lane Belt; and (2) the left-lateral, strike-slip to oblique-slip faults that are kinematically linked to the former structures (see above and Stewart, 1988). Northerly-trending high-angle normal faults - so-called "Basin-and-Range" structures - are associated with the prominent and similarlyoriented opaline sinter deposit of the "Main Terrace," along and flanking U.S. Highway 395 at the eastern edge of the Hills (Figure 1). However, the youngest hot-spring vents in the Main Terrace clearly formed in northwest-trending, highangle tension gashes.

\section{The Steamboat Gravity Slides}

In-progress geologic mapping by the authors and Gregory D. Nash (EGI) has revealed that much of the Miocene Kate Peak Formation volcanic cover (at least $8 \mathrm{~km}^{2}$ ) in the western half of the Steamboat Hills (Figure 1) is actually chaotic breccia in a previously much more extensive gravity-slide complex derived from the Sierran highlands to the west. Clasts in the gravity-slide breccia range from centimeter- to 20-m-size, and include not only Kate Peak andesites and lahars but also small amounts of Sierran granitoid and Triassic metamorphic rock. A basal part of the slide breccia, consisting of intensely fractured and locally rubblized metasiliciclastic rock a little west of the central crest of the Hills (Figure 1), until recently was commercially mined - without the need for explosives (Peter van de Kamp, 1995, personal communication)_for road ballast and other aggregate applications. A main goal of our investigation is ascertaining the relationship (if any) between these large-scale gravity slides and shallow, subhorizontal, thermal-fluid aquifers in the northern Steamboat Hills.

\section{Hydrothermal Alteration and Mineralization}

The rocks of the Steamboat Hills have been affected extensively not only by the modern geothermal system, but by a succession of older systems active at unknown intervals since probably the late Cretaceous. The gaudy, exposed, advanced argillic (or "acid-sulfate") alteration spatially associated with late Quaternary siliceous sinter is broadly contemporaneous with these hot-spring deposits, but is still an active process (White, 1968): Steaming ground and fumaroles genetically affiliated with the advanced argillic alteration are prominent features of the modern geothermal field.

The advanced argillic alteration affects Cretaceous granitoid, the Lousetown Basaltic Andesite, the Alta and Kate Peak Formations, and surficial deposits including phreatic lithic tuff. This type of alteration, in the extreme case, is notable for complete destruction or transformation of all major rock-forming phases except quartz, resulting in a soft, porous, commonly whitish and powdery aggregate dominated by the quartz with kaolinite and alunite (Schoen and White, 1967; Schoen et al., 1974), and locally accompanied by native sulfur and cinnabar.

In northern Steamboat geothermal wells, advanced argillic alteration gives way progressively downward into: (1) a less acid-stable, smectite-rich argillic assemblage; (2) an underlying mixed-layer illite-smectite (I/S) assemblage; then (3) propylitically altered and locally sericitized (I/S and illite), silicified, and (rarely) adularized host rock (White et al., 1964; Schoen and
White, 1974). Geologic mapping, well-logging, and mineralogic analysis completed by the authors since these pioneering studies has shown that all of these geologically recent alteration assemblages overprint more coarsely-crystalline clay-sericite (quartz-I/S), phyllic (quartz-illite or -muscovite), and propylitic alteration that must have developed in the older hydrothermal systems.

\section{The Geothermal System}

Although high-angle faults prevail at the surface of the Steamboat Hills (Figure 1), the principal producing thermalfluid aquifers $\left(155-235^{\circ} \mathrm{C}\right)$ at depth are clearly subhorizontal features (van de Kamp and Goranson, 1990; Sorey and Colvard, 1992; Mariner and Janik, 1995; De Rocher, 1996; Johnson and Hulen, 2005). These gently-dipping and likely fault-controlled aquifers form two tiers - a deeper, higher-temperature $\left(200-235^{\circ} \mathrm{C}\right)$ zone at an average depth of about 900 $\mathrm{m}$ in the vicinity of the "upper power plant" (Figure 1); and a shallower, moderate-temperature $\left(155-180^{\circ} \mathrm{C}\right)$ tier that now variously supports or will support the "lower power plants" at the northeastern edge of the Steamboat Hills. Van de Kamp and Goranson (1990) and DeRocher (1996) suggested that these thermal aquifers are the productive portions of two separate geothermal systems. Sorey and Colvard (1992) and Mariner and Janik (1995), on the other hand, provided compelling geochemical evidence that the two "tiers" are actually interconnected portions of the same system.

Typical production from the "shallow-tier" thermal aquifer is about 8000 liters per minute of dilute $(\sim 3000$ ppm total dissolved solids), sodium-chloride water at a temperature of about $165^{\circ} \mathrm{C}$ from a major fracture zone in granodiorite at an elevation of $\sim 1200 \mathrm{~m}$ (data from ORMAT field-development records). In this typical well, temperatures below the producing fracture zone show a slight progressive reversal down to the borehole's total depth. In cores from the "slim holes" drilled in this part of the field, the structures controlling major thermal-fluid entries are seen to comprise fractures with individual apertures up to several centimeters in width.

Major upflow zones feeding the lower and upper tiers of the Steamboat geothermal system have been hypothesized (e.g., Mariner and Janik, 1995), but not actually encountered. It has long been assumed that the "parent" upflow for the system is beneath the higher-temperature $(\sim 900 \mathrm{~m})$ lower-tier thermal aquifer in the vicinity of the upper power plant (Figure 1). However, none of this area's numerous deep wells (up to $~ 1.6$ $\mathrm{km}$ ) have encountered evidence for such a feeder.

Based on spatial relationships among hydrothermal alteration, siliceous sinter, and radiometrically-dated volcanic rocks, Silberman et al. (1979) estimated that the geologically recent Steamboat geothermal system began to form at $\sim 3 \mathrm{Ma}$. These authors conceded that if this age is realistic, the system almost certainly has been intermittently rather than continuously active for such a long span of time. In other words, the system has been repeatedly rejuvenated, either by influx of new magma batches, or through re-faulting and re-fracturing during periods of particularly intense seismicity, enabling "deep-circulation" heating. Multiple episodes of hydrothermal activity are recorded in the Steamboat Hills by: (1) Extinct hot-spring 
vents in portions of the field distant from recent hot springs; (2) hydrothermal alteration clearly pre-dating the Lousetown Basaltic Andesite in some portions of the field, but just as clearly post-dating the formation in other sectors; (3) intense alteration at most thermal-fluid entries, but minimal alteration at some. The evidence for long-term but intermittent hydrothermal activity at Steamboat permits the possibility that structural controls for this activity have also varied with time. It is within this context that we examine the potential roles of low-angle extensional faults, gravity slides, and ancient breccia bodies in the Steamboat field's intricate hydrothermal evolution.

\section{Geology of the New Wells}

\section{Methods and Procedures; General Observations and Comments}

The new wells at Steamboat were drilled in the northeastern part of the field, where thermal-fluid production has traditionally been from shallow elevations on the order of $1200 \mathrm{~m}$ (ORMAT field-development records). Three of the

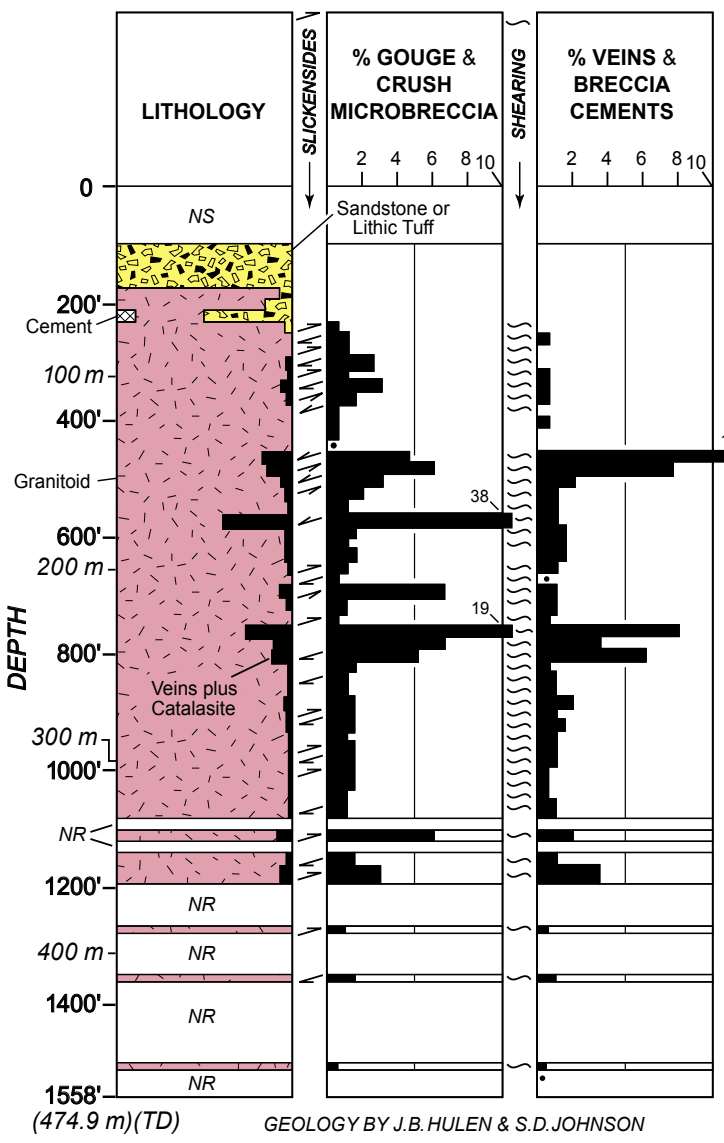

Figure 2. Summary geologic log for production well 34-32, in the north-central Steamboat geothermal field (Figure 1). Please also see the accompanying Explanation. As targeted, the well encountered a "flat-fault"-controlled, moderate-temperature thermal aquifer at about $340 \mathrm{~m}$ depth. In this well and the others shown on Figure 1, the geologic parameters signaling the deeper presence of the thermal aquifer are silicified cataclasite and euhedral quartz crystals in epithermal veins. Molybdenite and chalcopyrite in the granitoid host rock of 34-32 are distinctly anti-correlated with the fluid-entry zone, and are believed to record a magmatic-hydrothermal system of likely late Cretaceous age. wells (34-32, 42-32, and 44-32; Figure 1) were completed in a previously undrilled region west of the historic Silica Pit; and two production wells (38-28 and 78-29) were drilled in the already partially developed Sinter Hill-Main Terrace area (Figure 1). A replacement-injection well (64A-32; Figure 1) relevant to this study had been drilled in 2004 in close proximity to deteriorating injector Cox I-1 (not illustrated), which for years had been accepting, without apparent limit and at a rate of several hundred thousand $\mathrm{kg} / \mathrm{hr}$, all the spent production fluid from the deeper and hotter lower-tier thermal aquifer in the southern part of the field. All six of the new wells were commercial successes.

Detailed geologic descriptions and logs for two of the new wells (34-32 and 64A-32; Figures 2 and 3) and summary descriptions of two others (42-32 and 44-32; Figure 1) from among the drilled six are the basis for further discussion. For each of these wells, lithology and hydrothermal alteration/ mineralization, along with evidence for structural or hydrothermal disruption (gouge, crush microbreccia, veinlets, and variously-textured breccias), were used in combination to help constrain active and extinct fluid channels. Modern commercial thermal-fluid entries were identified using a variety of parameters including: those noted above; information from drilling (e.g., lost-circulation zones); and static temperature/ pressure profiles.

\section{Lithology}

The six subject wells penetrated mostly hornblendebiotite granodiorite (Figures 2 and 3), which in the northern Steamboat field is the host rock for the shallow-tier thermal aquifer. The granodiorite is medium-crystalline, and consists primarily of quartz, K-feldspar, plagioclase, and biotite, with accessory hornblende and magnetite and trace to minor amounts of titanite (sphene). In wells from which shallower cuttings were collected, the granodiorite is overlain by Lousetown Basaltic Andesite flow rocks, breccias, and affiliated scoria; and by arkosic sandstone or what could be, just as readily, compositionally equivalent, phreatic lithic tuff (Figures 2 and 3). If the latter characterization is correct, the tuff was probably erupted from vents such as the well-known one at the northern edge of the Steamboat Hills. 


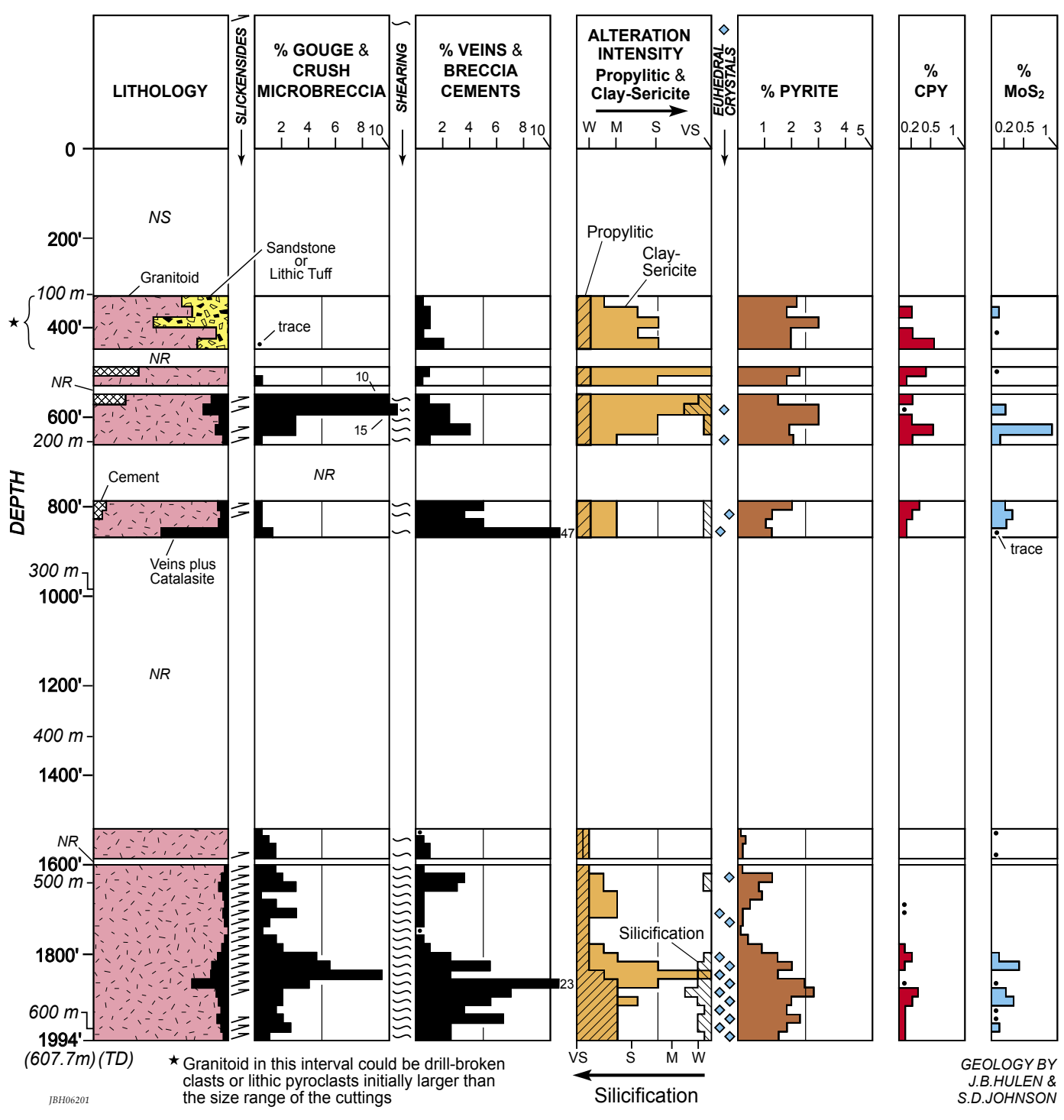

Figure 3. Summary geologic log for Steamboat injection well 64A-32 (Figure 1). Please also see the accompanying Explanation. The "upper-tier" structural aquifer penetrated in well 34-32 (Figure 2) was also encountered in 64A-32, but at about $270 \mathrm{~m}$ depth. The deepest portion of the well, in the depth range $540 \mathrm{~m}$ to $>608 \mathrm{~m}$, coincides with a highly porous and permeable, Cu-Mo-mineralized breccia, clasts of which are coated with drusy epithermal quartz. This zone accepts—apparently without limit—all of the spent production fluid from the deeper and hotter southern part of the Steamboat field (in the vicinity of the "upper power plant"; Figure 1). We hypothesize that the injection-zone breccia is part of a late Cretaceous, magmatic-hydrothermal breccia pipe with considerable relict porosity.

\section{Evidence for Rock Rupture}

Granodiorite in the study wells is extensively disrupted by gouge and crush microbreccia (as distinct from drillingproduced "bit gouge"; Hulen and Sibbett, 1982), features that appear in nearly every 3-m sample examined (Figures 2 and 3). This pervasive cataclasite distribution recalls that observed in large-scale gravity slides (French, 1993) and in detachmentfault upper plates (e.g., Hulen et al., 2005, 2005b) that have moved significant distances but have remained relatively intact while escaping wholesale rubblization.

Evidence for profound dilational faulting in the study wells was the total loss of drilling fluid that took place in all six boreholes (Figures 2 and 3 ) at $\sim 350 \mathrm{~m}$ depth. Occurring in the same narrow elevation range $(1150-1250 \mathrm{~m})$ in wells spaced up to $1.6 \mathrm{~km}$ apart, these lostcirculation zones coincide with the shallow-tier thermal aquifer penetrated throughout the northern Steamboat geothermal field.

\section{Hydrothermal Alteration}

The study-well granodiorite is pervasively hydrothermally altered to a greater or lesser extent (Figures 2 and 3). Propylitic and clay-sericite alteration affect the intrusive in almost every sample. "Clay-sericite" alteration for this paper is a provisional classification based strictly on examination of the cuttings with a conventional binocular microscope. From this perspective, clay-sericite encompasses argillic (smectite), intermediate argillic (mixed-layer I/S), and phyllic (quartz-illite or quartzmuscovite) alteration, as well as superimposed, still-active, advanced argillic (kaolinite \pm alunite) alteration in the upper reaches of the boreholes. Planned petrographic and X-ray diffraction studies of the altered rocks will enable more refined characterization of the constituent alteration types and their textural and paragenetic relationships.

The clay-sericite and propylitic alteration assemblages encountered in the study wells are clearly the combined products of the active and extinct hydrothermal systems. Based on empirical mineral/temperature relationships (Browne, 1996), various secondary-mineral geothermometers for the wells indicate hydrothermal paleotemperatures of at least $300^{\circ} \mathrm{C}$ in altered rocks where modern temperatures nonetheless are as low as $40^{\circ} \mathrm{C}$.

\section{Dilational Breccias and Microbreccias}

The granodiorite penetrated in the study wells has locally undergone intense dilational brecciation, recognizable by a distinctive "jigsaw-puzzle" texture (e.g., Sillitoe, 1985) even at the scale of the drill chips. This texture is especially common in the 60-m-thick breccia zone at the bottom of well 64A-32 (Figure 3). Evidence for voluminous open space in this breccia 


\title{
EXPLANATION FOR SUMMARY GEOLOGIC LOGS OF STEAMBOAT GEOTHERMAL WELLS 34-32 AND 64A-32
}

\author{
Lithology
}

ARKOSIC SANDSTONE OR PHREATIC LITHIC TUFF, POORLY-SORTED, VERY FINE- TO COARSE-GRAINED; OVERALL LIGHT GRAY-BUFF; WEAKLY CONSOLIDATED; QUARTZ AND FELDSPAR GRAINS ANGULAR TO SUBANGULAR; BIOTITE GRAINS "SHREDDY," INITIALLY SHINY BLACK BUT NOW LIGHT TO MEDIUM BRONZY-BROWN; CLASTS ARE WEAKLY CEMENTED IN PART WITH WHITISH CLAY \pm MICROCRYSTALLINE GRAYISH PYRITE; ASSOCIATED, >1.5 MM GRANITOID CHIPS ARE PROBABLY DRILLING-DISAGGREGATED PEBBLES, COBBLES, OR LITHIC PYROCLASTS.

HORNBLENDE-BIOTITE GRANITOID, PROBABLY GRANODIORITE; FINE- TO MEDIUMCRYSTALLINE; SUBHEDRAL-GRANULAR TEXTURE; 7-10\% BIOTITE,1-2\% HORNBLENDE, $15-20 \%$ QUARTZ, 1\% MAGNETITE, TRACE TITANITE (SPHENE); REMAINDER PLAGIOCLASE>POTASSIUM FELDSPAR.

VEINS, VEINLETS, BRECCIA CEMENTS, GOUGE, AND CRUSH MICROBRECCIA, UNDIVIDED.

\section{Alteration}

PROPYLITIC: MAFIC MINERALS PARTIALLY TO COMPLETELY ALTERED TO CHLORITE \pm MINOR CALCITE AND RARELY EPIDOTE; FELDSPARS (ESPECIALLY PLAGIOCLASE) WEAKLY ALTERED TO CHLORITE \pm TRACE TO MINOR CALCITE AND EPIDOTE; TITANITE (SPHENE) GENERALLY ALTERED TO LEUCOXENE \pm CALCITE; SECONDARY ALBITE LIKELY, BUT CONFIRMATION WILL REQUIRE PETROGRAPHY.

CLAY-SERICITE: FELDSPARS (ESPECIALLY PLAGIOCLASE) ALTERED TO MIXED-LAYER ILLITE/SMECITE \pm MICROCRYSTALLINE MUSCOVITE (ACCOMPANYING MOLYBDENITE AND CHALCOPYRITE); OVERPRINTED BY ARGILLIC AND ADVANCED ARGILLIC ALTERATION ABOVE ABOUT $200 \mathrm{~m}$ DEPTH.

SILICIFICATION: GOUGE, CRUSH MICROBRECCIA AND (LESS COMMONLY) FELDSPARS AND MAFIC MINERALS ALTERED TO MASSIVE MICROCRYSTALLINE QUARTZ (MOSTLY $<50 \mu \mathrm{m}$ GRAINS)

\section{Abbreviations}

$\begin{array}{cc}\text { BTE - BIOTITE } & \mathrm{mm}-\text { MILLIMETERS } \\ \text { BXCF - BRECCIA- } & \mu \mathrm{BX}-\text { MICROBRECCIA } \\ \text { CEMENT } & \mu \text { XLN - MICRO- } \\ \text { FRAGMENTS } & \text { CRYSTALLINE } \\ \text { CAL - CALCITE } & \text { MOS }- \text { MOLYBDENITE } \\ \text { CHL - CHLORITE } & \text { NR - NO (DRILLING) RETURNS } \\ \text { CMT - CEMENT } & \text { NS - NO SAMPLE } \\ \text { CPY - CHALCOPYRITE } & \text { PY - PYRITE } \\ \text { DIA - DIAMETER } & \text { S - STRONG } \\ \text { FSP - FELDSPAR } & \text { SER - SERICITE } \\ \text { GEN - GENERALLY } & \text { SMPL - SAMPLE } \\ \text { GG - GOUGE } & \text { TD - TOTAL DEPTH } \\ \text { HM - HEMATITE } & \text { VS - VERY STRONG } \\ \text { HEM - HEMATITE } & \text { VVF - VEINS AND VEIN } \\ \text { m - METERS } & \text { FRAGMENTS } \\ \text { M - MODERATE } & \text { XLN - CRYSTALLINE } \\ \text { MED - MEDIUM } & \text { XL(S) - CRYSTAL(S) } \\ \text { MFC - MAFIC } & \text { XRD - X-RAY DIFFRACTION } \\ & \end{array}$

\section{Symbols}

$$
\begin{aligned}
\% & - \text { PER CENT } \\
₹- & - \text { SLICKENSIDES } \\
\bullet & - \text { TRACE } \\
1 & - \text { FEET } \\
\& & - \text { AND } \\
\diamond & - \text { EUHEDRAL } \\
& \text { HYDROTHERMAL } \\
& \text { CRYSTALS } \\
\sim & - \text { SHEARING AND } \\
& \text { GRANULATION } \\
\mu & - \text { MICRO(N) } \\
\pm & - \text { WITH OR WITHOUT } \\
< & - \text { LESS THAN } \\
\leq & - \text { LESS THAN OR } \\
& \text { EQUAL TO } \\
> & - \text { GREATER THAN }
\end{aligned}
$$

fault-zone origin. However, these features clearly post-date the brecciation, and (as in the upper plate of the low-angle fault-controlled aquifer) could record pervasive (as opposed to fault-focused) postbreccia cataclasis.

The presence of significant amounts of molybdenite, chalcopyrite, and secondary muscovite in the deep 64A-32 breccia favors rock rupture by magmatic-hydrothermal mechanisms (modes 2 and 3 above). Many such breccias throughout the world are richly mineralized and cemented with a wide variety of hydrothermal phases (features recording high paleo-permeability). Those breccias are also commonly affiliated, genetically and spatially, with relatively coarse-grained phyllic alteration, as in 64A-32. The breccia bodies that still retain considerable relict porosity probably formed not by hydrothermal explosion, but by rock collapse into large (tens to hundreds of meters across) magmatic-vapor bubbles (Norton and Cathles, 1973). We will pursue this possibility for Steamboat in the "Discussion and Conclusions" section of the present report.

\section{Hydrothermal Veins and Breccia Cements; Mineralization}

Most cuttings samples from the study wells contain at least minor amounts of hydrothermal openspace-filling material, including hydrothermal veinlets and breccia cements along with whole drill chips of compositionally equivalent material (Figures 2 and 3). The latter are likely derived from veins and interclast cements that exceed the size of the cuttings (typically is provided by clasts (up to $10 \mathrm{~mm}$ in diameter) almost entirely coated with epithermal drusy quartz. In some of the larger chips, the actual interclast pores are partially preserved in the drill-broken remains of quartz-cemented clast aggregates.

The jigsaw-puzzle textures of the deep 64A-32 breccias could indicate formation by (1) implosion in a dilational fault zone; (2) hydrothermal explosion; (3) rock collapse into an underground cavity; or (4) a combination of all these processes. Textures indicating granulation, shearing, and slickensiding in rock chips from this breccia zone would seem to support the
0.5-5 mm). The open-space-filling minerals, accounting for up to $50 \%$ of 20 -m-composite samples in the two exemplary wells, consist principally of quartz \pm calcite and probably adularia in various proportions with lesser pyrite and marcasite (and probably other metallic phases). Calcite-rich veins appear "clean" and white, and typically contain only traces of of pyrite and marcasite. Quartz-rich veins are commonly "polluted" with rock debris, and have much higher sulfide concentrations (up to $10 \%$ ), locally including conspicuous molybdenite and chalcopyrite. 
In whole cuttings samples, combined amounts of molybdenite and chalcopyrite range from a trace to $1.4 \%$ over $6-\mathrm{m}$ drilling intervals, and up to $2.5 \%$ over 3 -m intervals. These ore sulfides occur (1) as fine- to relatively coarse-crystalline (up to $3 \mathrm{~mm}$ ), granodiorite-hosted disseminations without apparent fracture control; and (2) as similarly-textured crystals and crystalline aggregates with or without pyrite in massive translucent white quartz. Concentrations of the ore sulfides over intervals of tens of meters approach currently commercial grades in some porphyry Mo-Cu orebodies (say, $0.15 \% \mathrm{MoS}_{2}$ and $0.1 \% \mathrm{Cu}$ ).

\section{Discussion and Conclusions}

The occurrence of the shallow-tier thermal aquifer at essentially the same elevation throughout the northern Steamboat field - and in wells up to $1.6 \mathrm{~km}$ apart — exceeds the constraints of coincidence. We contend that this relationship provides nearly unequivocal evidence for shallow thermal-fluid distribution in a subhorizontal normal fault zone. Furthermore, there is no reason to believe that this is a rare phenomenon in western U.S. geothermal systems. It is highly likely that such

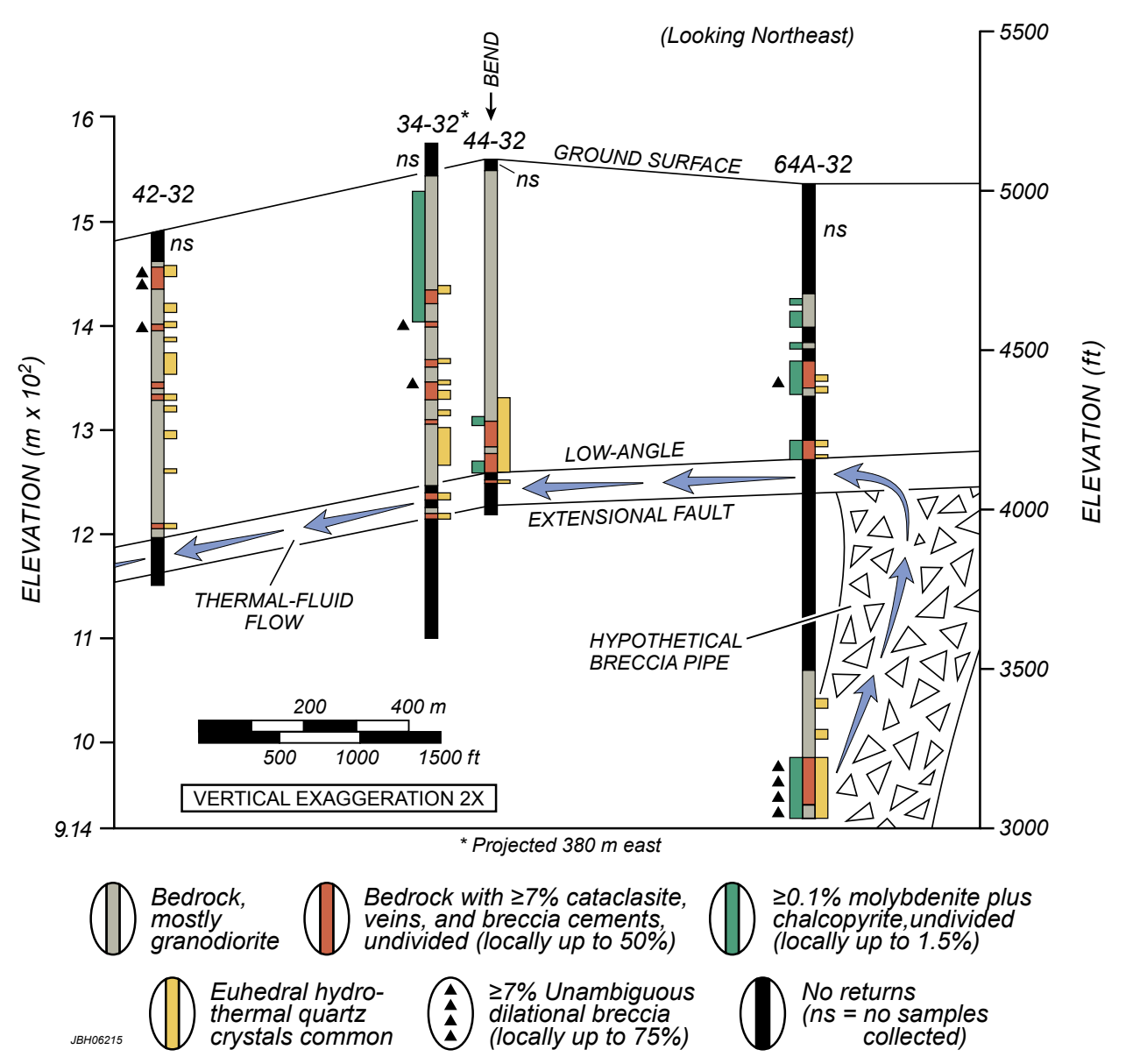

Figure 4. Revised conceptual model for thermal-fluid upflow and outflow in the northern part of the Steamboat geothermal field. Key elements of the model, based on recent drilling results, are (1) an upflow zone controlled by relict porosity and permeability in a fossil magmatic-hydrothermal breccia pipe channeling hot fluid into (2) an areally extensive low-angle extensional fault that truncates the top of the pipe. The "flat-fault" thermal aquifer, perhaps additionally fed from below by other such ancient breccia bodies, distributes hot fluid throughout the northern Steamboat geothermal field. gently-dipping fault-controlled thermal aquifers are integral elements of numerous moderate- to high-temperature geothermal systems identified and certainly yet to be found throughout the Basin and Range province.

Observations and measurements from our ongoing investigation of the Steamboat geothermal field to date have led us to the following conclusions, speculations, and revised conceptual geologic model (see also Figure 4) for the northern part of the field:

- The field's upper-tier thermal-fluid aquifer is a low-angle extensional fault zone spanning at least $3 \mathrm{~km}^{2}$ and essentially confined throughout this area to the narrow elevation interval 1150-1250 m. Field mapping has revealed extensive low-angle faulting and gravity sliding throughout the Steamboat Hills (this paper and Johnson and Hulen, 2005), but at seemingly too high an elevation range for obvious connection to the upper-tier aquifer. Johnson and Hulen (2005) also noted widespread listric faulting at multiple scales throughout the Steamboat Hills. The larger of these listric faults conceptually could sole into the upper-tier fault zone; the smaller could bound rotated hanging-wall blocks. Additional detailed mapping should thoroughly test these possibilities.

- In drill cuttings and cores, the uppertier aquifer is commonly but not invariably signaled at shallower elevations by anomalous concentrations of silicified cataclasite along with euhedral quartz crystals in epithermal veinlets and breccia cements (Figures 2, 3, and 4). The granodiorite hosting these features is altered to propylitic and clay-sericite assemblages not particularly well correlated with the aquifer.

- Porphyry-type $\mathrm{Cu}-\mathrm{Mo}$ mineralization is found locally above the upper-tier aquifer. In this structural position, the mineralization shows no systematic relationship to the aquifer.

- On the other hand, similar $\mathrm{Cu}-\mathrm{Mo}$ mineralization in injection well 64A32 coincides directly with a $540 \mathrm{~m}$ to $>608 \mathrm{~m}$-deep, highly porous and permeable breccia (Figures 3 and 4) that is also the zone accepting the entire spent-fluid yield from the southern part of the Steamboat resource. This breccia "sponge" is likely of ancient magmatic-hydrothermal origin, but it has undergone subsequent cataclasis. Conceptually, this cataclasis could have taken place in the upper plate of a still-deeper sub-horizontal extensional fault zone. We suggest that this deeper "flat fault" could be the one controlling the Steamboat field's higher-temperature "lower-tier" thermal aquifer. 
Based on these findings, we have modified our initial low-angle fault model for the Steamboat geothermal field to propose the following dual hypothesis: The upper-tier thermal aquifer is fed from below by one or more upflow zones opportunistically exploiting, as we surmise in well 64A-32 (Figure 4), breccia bodies ("pipes" for simplicity of reference) inherited from a long-extinct, $\mathrm{Cu}$-Mo-bearing magmatic-hydrothermal system probably affiliated genetically with the late Cretaceous Steamboat granodiorite.

At the scale of the cuttings ( $\leq 10 \mathrm{~mm}$-diameter chips), the $\mathrm{Cu}-\mathrm{Mo}$-bearing breccia is texturally reminiscent of Mesozoic to early Cenozoic, porphyry-style breccia pipes such as those at Hanover-Fiero (southwestern New Mexico); Patagonia (south-central Arizona); and elsewhere along the North and South American cordillera (Norton and Cathles, 1973; Saegert et al., 1974; Norton, 1982; Sillitoe, 1995; and D.L. Norton, pers. comm., 2006). Textural relationships among breccia fragments and their drusy-quartz coatings in the deep breccias of well 64A-32 permissively point to much larger clasts (and correspondingly larger interclast pores) that were fragmented during the drilling process, and perhaps earlier during postbreccia cataclasis.

Despite their age, many of the ancient breccia pipes retain considerable interclast porosity. For example, La Caridad pipe (Sonora, Mexico), has abundant angular cavities ranging from 2 to $10 \mathrm{~cm}$ in diameter (Saegert et al., 1974). The Whim Hill and Lee Hill pipes in southwestern New Mexico's Santa Rita district have interconnected openings ranging "from pinhole- through football- to human-sized" (D.L. Norton, pers. comm., 2006), and the Four Metals pipe in southern Arizona's Patagonia district has been likened to "a rubble pile...[with] enormous open spaces" (Norton, 1982). If these older pipes were placed conceptually into a modern geothermal system, there is no doubt that they would readily store and transmit large volumes of thermal fluid. We contend that this could be precisely the case in the Steamboat geothermal field.

Figure 4 graphically portrays our revised northern Steamboat conceptual model. According to the model, gradually cooling, higher-temperature thermal fluids - initially heated by "deep circulation" - ascend in an upflow zone controlled by a fossil, $\mathrm{Cu}-\mathrm{Mo}$-bearing, probable late Cretaceous breccia pipe that has retained much of its initial porosity and permeability. The breccia pipe has been "beheaded" by the areally extensive low-angle fault zone that is also the Steamboat field's upper-tier thermal aquifer. Hot fluids in the truncated upflow zone are diverted into this gently-dipping structure beneath a fractured and brecciated but overall hydrothermally sealed caprock. With few exceptions, $\mathrm{Cu}$-Mo mineralization above the low-angle fault zone is not obviously breccia-controlled. However, this upper-plate mineralization could readily be part of the larger magmatic-paleohydrothermal system within which the breccia pipe formed.

The location of the displaced upper part of the conceptually beheaded breccia pipe is still a matter for conjecture, as the direction and magnitude of displacement on the truncating low-angle fault zone remain to be determined. In the realm of pure speculation, such pipe tops, if they closely approached or even breached the recent ground surface, would have been ideal foci for Steamboat's well-known and locally large-volume late Cenozoic phreatic eruptions.

The roles that the newly-recognized, older mineralized breccias at Steamboat play in the field's deeper permeability architecture are also conjectural subjects at this stage of the investigation. Certainly, the hotter, "lower-tier" thermal aquifer, like its shallower counterpart to the north, could be fed from even deeper levels in a pipe-controlled upflow zone. There is also the intriguing possibility that the postulated but enigmatic connection between the upper- and lower-tier aquifers (see Mariner and Janik, 1995) is a breccia-pipe segment truncated at its top and base by low-angle extensional faults.

\section{Final Note: Drilling Success and Technology Transfer}

Results of this DOE-ORMAT-supported investigation have demonstrated beyond doubt the practical value of government-industry collaborative geothermal research. While clearly (as DOE-specified) relevant to the entire geothermal industry, our low-angle-fault research also has been instrumental in ORMAT's recent Steamboat drilling success. Drilling plans for the three new "step-out" wells west of the Silica Pit (Figure 1) took into account proximity to previously mapped high-angle faults, but the actual drilling target was the shallow, "flat-fault" thermal aquifer hypothesized in our 2004 grant proposal (Hulen and Johnson, 2004), and essentially confirmed shortly thereafter. All three wells penetrated the productive, gently-dipping structure in the predicted narrow depth range, and all three wells are set to supply copious volumes of thermal fluid for the Galena II electric-power plant.

While no longer considered part of DOE's EGS program in the strictest sense, this research project and its findings thus far are clearly germane to the conceptual creation of Enhanced Geothermal Systems. The locations, configurations, and controlling local stress regimes of known or potential "Steamboattype" low-angle fracture zones in extensional tectonic regimes can be discounted only at risk in the design and implementation of EGS fracture-stimulation procedures.

\section{Acknowledgements}

This work is being sponsored by DOE, Office of Geothermal Technologies (Grant No. DE-FG36-04GO14296); the University of Utah; and ORMAT Nevada, Inc. The authors greatly appreciate this support, and additionally wish to thank ORMAT for access to the study area and its research materials; for a generous in-kind contribution in the form of wellbore geophysical data and drill cuttings; and for permission to publish this paper. We also gratefully acknowledge expert advice on porphyry-style, $\mathrm{Cu}$-Mo-mineralized breccia pipes from Denis L. Norton, a geologist (Stanley, Idaho) who arguably knows these features better than anyone else. Greg Nash (EGI) has contributed remote-sensing expertise and geologic-mapping imagery as well as invaluable field support for the Steamboat Hills geologic mapping project. Illustrations are the work of graphic artist Douglas Jensen (mondello2@comcast.net; Salt Lake City, Utah). 


\section{References}

Browne, P.R.L., 1996, Hydrothermal alteration: Auckland, New Zealand, The University of Auckland, Course 665.611 Geology Lecture Notes, $66 \mathrm{p}$.

Castor, S.B., Garside, L.J., Henry, C.D., Hudson, D.M., MacIntosh, W.C., and Vikre, P.G., 2002, Multiple episodes of magmatism and mineralization in the Comstock district, Nevada: Geological Society of America, Abstracts with Programs, v. 34, p. 185.

DeRocher, T., 1996, Historical summary of Caithness Power, Inc., hydrologic monitoring of the Steamboat Hills region, 1987-present: Yankee-Caithness Joint Venture, Proprietary Draft Report, 46 p.

Flynn, T., Buchanan, P.K., and Miller, J.D., 1993, Core lithology and photographs, slim hole 87-29, Steamboat Hills, Nevada: University of Nevada, Las Vegas, Harry Reid Center for Environmental Studies and Marjorie Barrick Museum of Natural History, 20 p. (with numerous illustrations and appendices).

French, D.E., 1993, Debris slides of the Railroad Valley area, Nye County, Nevada-Yet another interpretation of Grant Canyon and Bacon Flat oil fields: American Association of Petroleum Geologists Bulletin, v. 77, p. 1448.

Hulen, J.B., and Johnson, S.D., 2004, Low-angle extensional tectonics, flat-fracture domains, and gravity slides in hydrothermal and EGS resources of the western United States: Proposal (now a funded project-Grant DE-FG36-04GO14296) to U.S. Department of Energy, Office of Geothermal Technologies.

Hulen, J.B., and Sibbett, B.S., 1982, Sampling and interpretation of drill cuttings from geothermal wells: Society of Professional Well Log Analysts, Reprint Volume, p. IV-3 to IV-54.

Hulen, J.B., Nash, G.D., and Deymonaz, J., 2005a, Geology of the Emigrant geothermal prospect, Esmeralda County, Nevada: Geothermal Resources Council, Transactions, v. 29.

Hulen, J.B., Nash, G.D., and Deymonaz, J., 2005b, "Hot prospect"-DOE enables the Emigrant geothermal exploration and slimhole drilling project in Fish Lake Valley, Nevada: Geothermal Resources Council Bulletin, v. 34, p. 176-183.

Johnson, S.D., and Hulen, J.B., 2005, Geologic observations bearing on low-angle fractures and gravity-slide blocks in the Steamboat Hills and Steamboat geothermal field, Washoe County, Nevada: Geothermal Resources Council, Transactions, v. 29, p. 281-289.

Lynne, B.Y., Moore, J., Browne, P.R.L., and Campbell, K.A., 2003, Age and mineralogy of the Steamboat Springs silica sinter deposit, Nevada, U.S.A.-A preliminary report on core SNLG 87-29: Auckland, New Zealand, $25^{\text {th }}$ New Zealand Geothermal Workshop, Proceedings, p. 65-70.

Mariner, R.H., and Janik, C.J., 1995, Geochemical data and conceptual model for the Steamboat Hills geothermal system, Washoe County, Nevada: Geothermal Resources Council, Transactions, v. 19, p. 191-197.

Nathwani, J., and Creed, R.J., 2002, DOE's Enhanced Geothermal Systems program: Geothermal Resources Council, Transactions, v. 26 , p. $235-236$.

Norton, D., 1982, The thermal history of magma-hydrothermal systems - Lithocaps and cupola regions in fossil systems, southeastern
Arizona: Tucson, Arizona, University of Arizona, Department of Geosciences, Field Manual, 83 p.

Norton, D.L., and Cathles, L.M., 1973, Breccia pipes-Products of exsolved vapor from magmas: Economic Geology, v. 68, p. 540-546.

Parsons, T., 1995, The Basin and Range province, $\underline{i n}$ Continental riftsEvolution, structure, and tectonics (K.H. Olsen, ed.): Amsterdam, Elsevier, 277-234.

Saegert, W.E., Sell, J.D., and Kilpatrick, B.E., 1974, Geology and mineralization of La Caridad porphyry copper deposit, Sonora, Mexico: Economic Geology, v. 69, p. 1060-1077.

Schoen, R., and White, D.E., 1967, Hydrological alteration of basaltic andesite and other rocks in drill hole GS-6, Steamboat Springs, Nevada, in Geological Survey research, 1967: U.S. Geological Survey, Professional Paper 575-B, p. B110-B119.

Schoen, R.W., White, D.E., and Hemley, J.J., 1974, Argillization by descending acid at Steamboat Springs, Nevada: Clays and Clay Minerals, v. 22, p. 1-22.

Silberman, M.L., White, D.E., Keith, T.E.C., and Dockter, R.D., 1979, Duration of hydrothermal activity at Steamboat Springs, Nevada, from spatially associated volcanic rocks: U.S. Geological Survey Professional Paper 458-D, 64 p.

Sillitoe, R.H., Ore-related breccias in volcanoplutonic arcs: Economic Geology, v. 80, p. 1467-1514.

Sorey, M.L., and Colvard, E.M., 1992, Factors affecting the decline in hot-spring activity in the Steamboat Springs area of critical environmental concern, Washoe County, Nevada: U.S. Geological Survey, Administrative Report for the Bureau of Land Management, 106 p., 7 appendices.

Stewart, J.H., 1988, Tectonics of the Walker Lane belt, western Great Basin-Mesozoic and Cenozoic deformation in a zone of shear, in Metamorphism and crustal evolution of the western United States (Rubey vol., W.G. Ernst, ed.): Englewood Cliffs, New Jersey, Prentice-Hall, p. 668-713.

Stewart, J.H., 1999, Geologic map of the Carson City 30- x 60-minute quadrangle, Nevada: Nevada Bureau of Mines and Geology, Map 118 , scale $1: 100,000$.

van de Kamp, P.C., and Goranson, C.B., 1990, Summary of the hydrological characteristics of the Steamboat Hills area, Nevada: Consulting Report for Caithness Power, Inc., and Yankee-Caithness Joint Venture, $60 \mathrm{p}$.

Vikre, P.G., McKee, E.H., and Silberman, M.L., 1988, Chronology of Miocene hydrothermal and igneous events in the western Virginia Range, Washoe, Storey, and Lyon Counties, Nevada: Economic Geology, v. 83, p. 864-874.

White, D.E., 1968, Hydrology, activity, and heat flow of the Steamboat Springs thermal system, Washoe County, Nevada: U.S. Geological Survey, Professional Paper 458-C, 109 p.

White, D.E., Thompson, G.A., and Sandberg, C.H., 1964, Rocks, structure, and geologic history of the Steamboat Springs thermal area, Washoe County, Nevada: U.S. Geological Survey Professional Paper 458-B, $63 \mathrm{p}$. 
PROCEEDINGS, Thirty-Fourth Workshop on Geothermal Reservoir Engineering

Stanford University, Stanford, California, February 9-11, 2009

SGP-TR-187

\title{
GEOLOGICAL AND STRUCTURAL RELATIONSHIPS IN THE DESERT PEAK GEOTHERMAL SYSTEM, NEVADA: IMPLICATIONS FOR EGS DEVELOPMENT
}

\author{
Susan Juch Lutz ${ }^{1}$, Joseph N. Moore ${ }^{2}$, Clay G. Jones ${ }^{2}$, Gene A. Suemnicht ${ }^{3}$, and Ann Robertson-Tait ${ }^{4}$ \\ 1 TerraTek, A Schlumberger Company, Salt Lake City, UT 84104 \\ 2 Energy and Geoscience Institute, University of Utah, Salt Lake City, UT 84108 \\ 3 ORMAT Nevada Inc., Reno NV 89511-1136 \\ 4 GeothermEx Inc., Richmond, CA 94806 \\ e-mail: slutz@salt-lake-city.oilfield.slb.com
}

\begin{abstract}
This paper integrates existing and new geologic information to develop a structural model of the Desert Peak geothermal system.

The major structural features of the field include: 1) a horst block composed of pre-Tertiary basement rocks that host the geothermal fluids; 2) vertical offsets of up to $1500 \mathrm{ft}$ on the northern and southern faults bounding the horst; 3) Jurassic metamorphic rocks in the horst rock directly overlain by silicified Tertiary tuffaceous rocks; 4) a thick package of pre-Tertiary weakly metamorphosed mudstones that overlies Jurassic rocks in non-productive, downdropped blocks north and east of the reservoir; 5) a Cretaceous granitic pluton northeast of the field, but not beneath the main production area; 6) a thick sequence of Tertiary basalt flows; and 7) the development of calcite veins and chlorite-bearing fault gouge along reactivated Mesozoic-age thrust faults separating major stratigraphic units in the basement rocks.
\end{abstract}

Well 27-15, the well proposed for hydraulic stimulation and creation of an enhanced geothermal system, is located north of the horst block in downthrown basement rocks. The proposed stimulation interval in this well is composed of complexly interstratified fault splices containing Jurassic-age diorites, Triassic phyllites, and hornfels that have undergone hydrothermal alteration and contact metamorphism. These rocks contain tourmaline, amphibole, and biotite that were deposited by high temperature magmatic fluids $\left(>325^{\circ} \mathrm{C}\right)$. Overlying pre-Tertiary mudstones in the upper part of the basement sequence, in contrast, contain only low to moderate temperature clay minerals $\left(<220^{\circ} \mathrm{C}\right)$. The two basement units are interpreted to be in fault contact. Formation imaging logs and temperature logs run in Well 27-15 document the presence of natural open fractures and minor fluid flow along these older fault contacts.

\section{INTRODUCTION}

The objectives of this study were to log selected wells to determine the distribution of rock types, faults, alteration minerals, and mineralized fractures, and then develop a geologic and structural model of the geothermal system based on this information. This information is then used to assess the continuity of target formations, the nature of formation contacts, the competency and potential geomechanical character of these formations, and to evaluate faults as potential barriers or conduits to fluid flow and the development of an enhanced geothermal (EGS) system.

The structural model presented in this paper is a conceptual interpretation based on analysis of mud logs, and X-ray diffraction and thin section analyses of well cuttings and core. The model incorporates new data from three wells located in the production portion of the well field (43-21, 74-21, and 77-21; Fig. 1), and previous well descriptions of Benoit et al., 1982; Lutz et al., 2004; Robertson-Tait et al., 2004). The emphasis of this work is on the preTertiary reservoir rocks, where temperatures reach $220{ }^{\circ} \mathrm{C}$. 


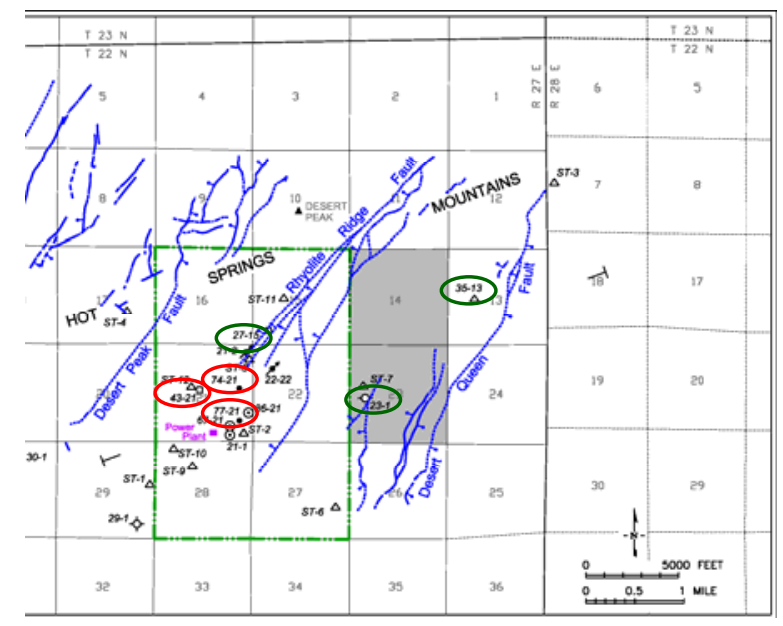

Figure 1: Location of wells in the Desert Peak geothermal field, most of the productive wells are located in Section 21. Wells circled in green represent previously studied wells, those circled in red are wells in the current study. Well 27-15 is the proposed EGS candidate well. Surface fault traces in blue are based on mapping by Faulds and Garside (2003).

\section{METHODS}

For the three 'in-field' wells (43-21, 74-21, 77-21), a total of about 100 well cuttings samples were analyzed by X-ray diffraction (XRD) methods. Whole rock and clay separates ( $<4$ micron) were analyzed to determine the mineralogy of major lithologies, and identify the clay, zeolite, and other hydrothermal alteration minerals at various depths through the geothermal system. In addition, the expandability of mixed-layer clays was determined to assess the competence of argillaceous lithologies and to evaluate clay zoning related to the geothermal system. Corresponding thin sections were made from the well cuttings at the same depths as the XRD samples. Using the mud logs for guidance, the sampling interval was nominally every 100 feet. Additional samples were collected where obvious lithologic breaks, structural features, or veined zones were noted on the mud logs.

The well cuttings were stored at the Nevada Bureau of Mines and Geology, and a small subset of the selected cuttings samples were collected for the XRD and petrology work. The preservation of these samples underscores the importance of maintaining repositories of drill samples and data.

\section{STRATIGRAPHIC RELATIONSHIPS IN THE STUDY BOREHOLES}

In general, the rocks exposed at the surface are Quaternary eolian deposits and lacustrine deposits from Pleistocene Lake Lahontan (the Truckee and Desert Peak Formations), Miocene basalts and andesites (Choropagus Formation), and Oligocene to Miocene rhyolitic to dacitic tuffs and lava flows, all variably faulted. The distribution of these outcropping Tertiary formations and exposed traces of recent faults in the northern Hot Springs Mountains have been mapped in detail by Faulds and Garside (2003). Subsurface rocks in the Desert Peak geothermal area are composed of late Oligocene to late Miocene volcanic and sedimentary rocks that rest directly on Mesozoic metamorphic and granitic basement. A thick sequence of variably altered Tertiary rhyolitic ash flow tuffs and lava flows overlies the eroded top of the buried metamorphic basement.

Based on the analysis of well cuttings, pre-Tertiary rocks in the Mesozoic basement are composed of three major rock packages. The uppermost package is composed of weakly metamorphosed, fine-grained dolomudstones and metasedimentary rocks of probable Jurassic age (the Pre-Tertiary 1 unit). The next package is a combination of complexly interstratified and faulted metamorphic rocks of Triassic to Jurassic age (the Pre-Tertiary 2 unit). Strongly metamorphosed, propylitically-altered diorites and hematitic metavolcanic rocks of the Jurassic Humboldt Mafic Complex (Johnson and Barton, 2000) are the dominant reservoir rocks in the Desert Peak geothermal field. Deformed metasedimentary rocks associated with the Humboldt Mafic Complex are recognized within the PreTertiary 2 unit and are correlative with the Boyer Ranch Formation where they are pure quartzites (Speed and Jones, 1969), or the Lovelock or Muttlebury Formations where they are carbonate or evaporite-rich (Johnson and Barton, 2000). Correlative quartz arenites and gypsum are exposed at the northern end of the Hot Springs Mountains and in the nearby Mopung Hills (Willden and Speed, 1974). In the six study drillholes, this sequence is generally recognized as silty dolomite, calcareous mudstone, or marble. South of the production area, the correlative unit in well 29-1 (Fig. 9) appears to be quartzite of the Boyer Ranch Formation (Benoit et al., 1982).

The third major rock type in the basement is an extensive granitic intrusive that underlies the metamorphic rocks north and east of the geothermal field. Well 23-1 to the east of the production area intersects the top of the Cretaceous granodiorite at about $7000 \mathrm{ft}$ (Fig. 8). Extensive thermal metamorphism of surrounding metasedimentary rocks has resulted in recrystallization to tourmaline, amphibole, and biotite.

In the following section, we compare the general stratigraphy in the proposed stimulation well (27-15) 
with the lithologies and alteration mineralogy in the three study wells within Section 21 (Fig. 1).

\section{Well 27-15}

Based on petrographic and X-ray diffraction analyses of selected well cuttings samples, the distribution of lithologies and secondary and alteration minerals in 27-15 is shown in Figure 2.

The contact between the Tertiary section and the Mesozoic basement rocks occurs at about $3300 \mathrm{ft}$ depth in this well. The top of the well is within basalt flows of the Miocene Chlorapagus Formation. The Tertiary sequence is dominated by ash flow tuffs and flows of rhyolite composition and is variably devitrified to quartz and potassium feldspar, and altered to smectite clay. The base of the Tertiary section is highly silicified and altered to mixed-layer illite-smectite (il/sm) along the contact with the basement rocks.

The upper part of the Mesozoic basement is comprised of shales and clay-rich dolomitic and calcareous mudstones of the Pre-Tertiary 1 Unit (Figure 2). These weakly metamorphosed mudstones are underlain by strongly propylitically-altered and metamorphosed diorites and phyllites of the PreTertiary 2 unit. The development of recrystallized, tourmaline-biotite-amphibole hornfels at the base of the well is interpreted to reflect hydrothermal alteration and contact metamorphism during intrusion of the Cretaceous granodiorite. The hornfels are characterized by well-defined metamorphic foliation with alternating quartz-rich and biotite-rich banding.

Even though 27-15 did not intersect the granitic body, it is present to the east in 23-1. Here, tourmaline and hydrothermal biotite are typically first encountered within about $1500 \mathrm{ft}$ of the granitic contact (Lutz et al., 2004). This suggests that the main granite body underlies or is close to the base of the $27-15$ well.

Because of the absence of metamorphic minerals in the Pre-Tertiary 1 mudstones and the distinct change in foliation and degree of metamorphism within the Pre-Tertiary 2 rocks, we interpret the sharp contact between Pre-Tertiary 1 and Pre-Tertiary 2 as a postintrusion fault that juxtaposes the two different rock suites.

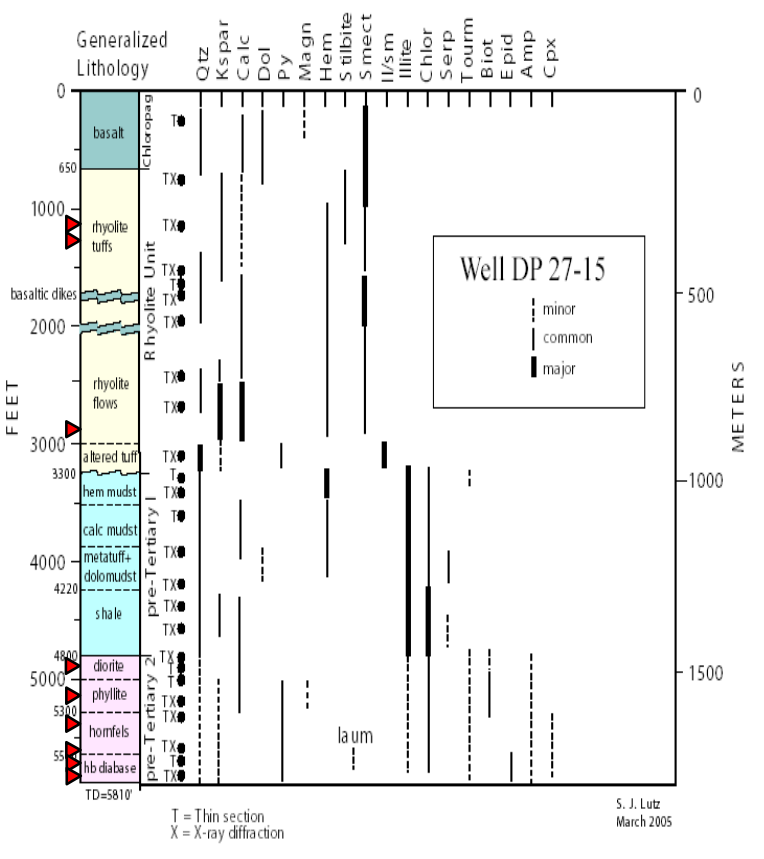

Figure 2: Lithologic column and distribution of secondary and hydrothermal alteration minerals in Well 27-15 (from Lutz, 2005). Red arrows show the locations of lost circulation zones.

\section{Well 43-21}

The upper part of 43-21 is generally similar to 27-15. However, in contrast to 27-15, the entire Pre-Tertiary 1 sequence of mudstones and shales is missing. Here the upper part of the basement is composed of Jurassic diorites of the Humboldt Mafic Complex, dolomitic rocks correlative to the Boyer Ranch/Lovelock Formations, and underlying hematitic and chloritic metasediments. Overall alteration is relatively weak, and the most significant geothermal minerals include the clay minerals: smectite (to depths of at least $1000 \mathrm{ft}$ ), mixed-layer illite-smectite (2000-3250 ft), and illite to the base of the well. The top of the illite- smectite zone implies temperatures of around $180^{\circ} \mathrm{C}$, while the top of the illite zone would indicate temperatures of near $220^{\circ} \mathrm{C}$ (Browne, 1993).

No cuttings samples were returned between about $1200 \mathrm{ft}$ and $2100 \mathrm{ft}$. This interval of lost circulation is interpreted as a major fault zone. 
43-21

\begin{tabular}{|l|l|}
\hline \multicolumn{2}{|c|}{ Table 1. Secondary and Hydrothermal } \\
Alteration Minerals:
\end{tabular}

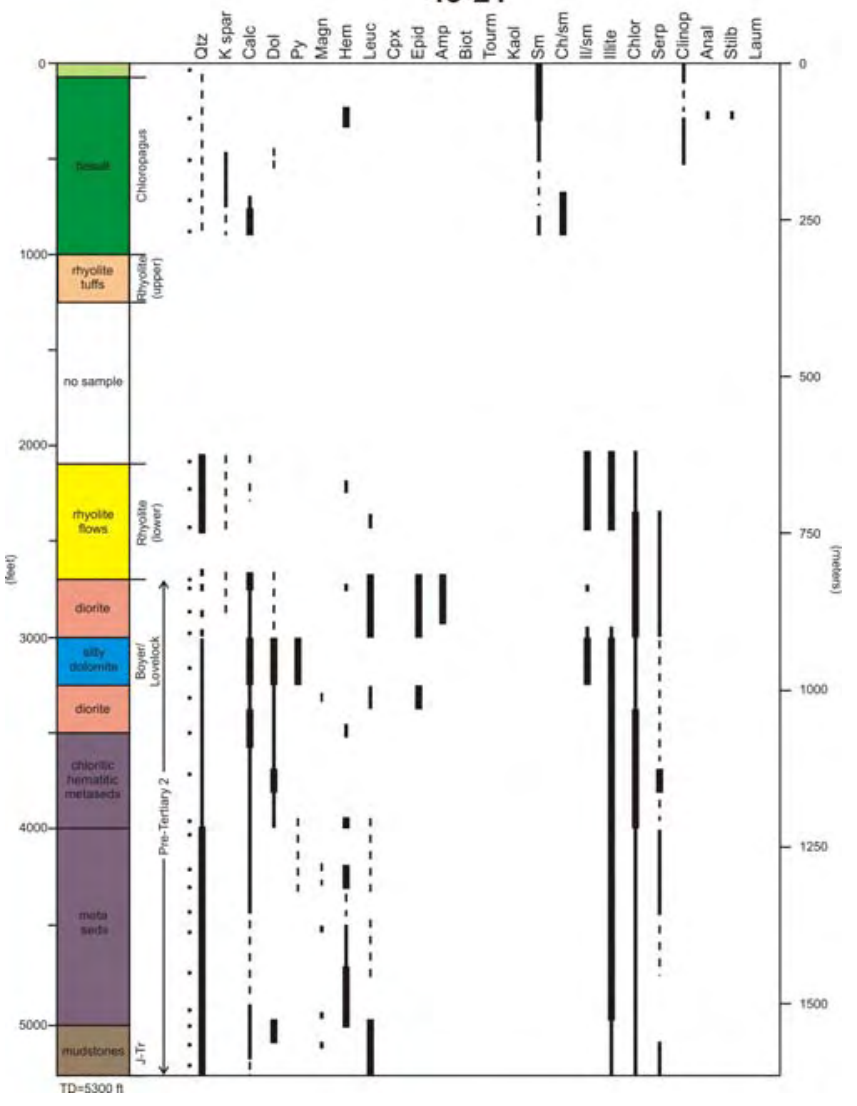

Figure 3: Lithologic column and distribution of secondary and hydrothermal alteration minerals in Well 43-21. No cuttings samples were collected from a thick lost circulation zone in the upper part of the well. 
74-21

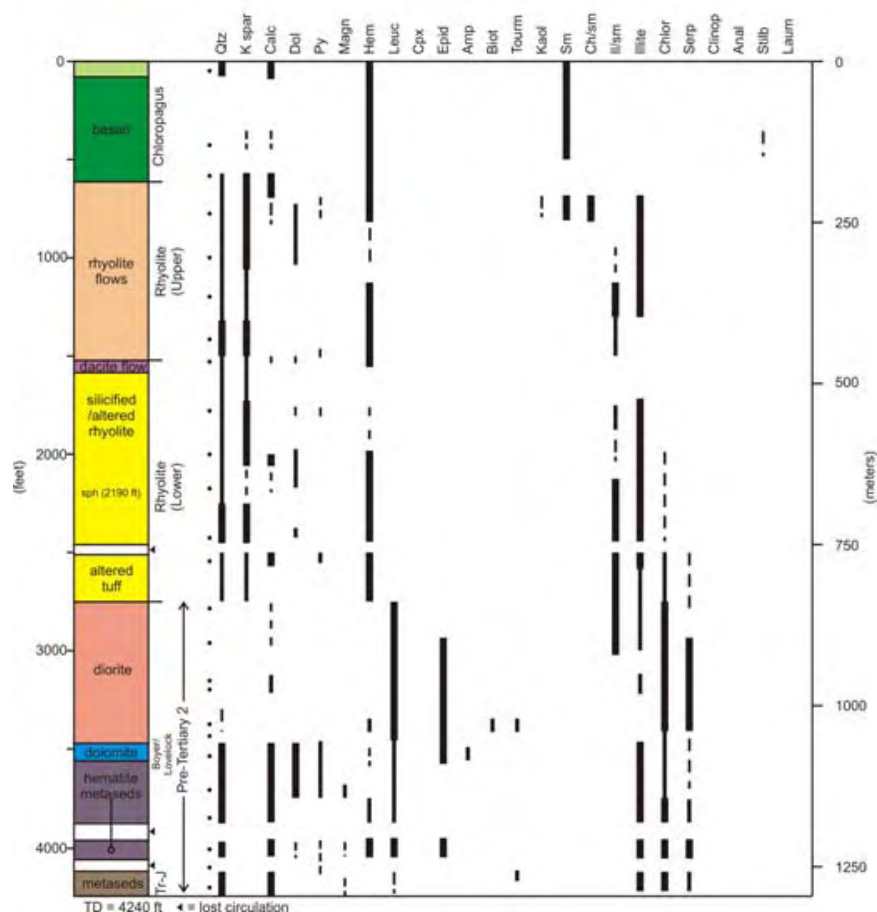

Figure 4: Lithologic column and distribution of secondary and hydrothermal alteration minerals in Well 74-21. Black arrows show the positions of lost circulation zones.

\section{Well 74-21}

The lithologies and stratigraphic relationships in 7421 are similar to 43-21. The basement rocks consist of Jurassic diorite and underlying metasedimentary rocks within the Pre-Tertiary 2 sequence. Mineral zoning is also similar; with shallow smectite and zeolite, followed by illite-smectite and illite. The top of the illite-smectite zone is shallower (at about 1000 $\mathrm{ft}$ depth) than in wells 43-21 and 27-15 (2100 ft and $3000 \mathrm{ft}$, respectively).

At least two lost circulation zones are present near the base of the well. Traces of amphibole, biotite and tourmaline in the Pre-Tertiary 2 sequence suggest that Cretaceous granite may be present within $1500 \mathrm{ft}$ of the well.

\section{Well 77-21}

The cuttings in 77-21 display alteration and rock type distributions (Fig. 5) similar to those in 43-21 and 7421. Zeolites and smectite occur in shallow portions of the well, followed by a thick mixed-layer illitesmectite zone extending close to the base of the well at $3640 \mathrm{ft}$.
As in 43-21 and 74-21, the upper part of the basement sequence is composed of Jurassic diorites in the Pre-Tertiary 2 sequence. Low-temperature geothermal veins in the basement are composed of anhydrite, and may be associated with open fractures and a lost circulation zone at about $3200 \mathrm{ft}$.

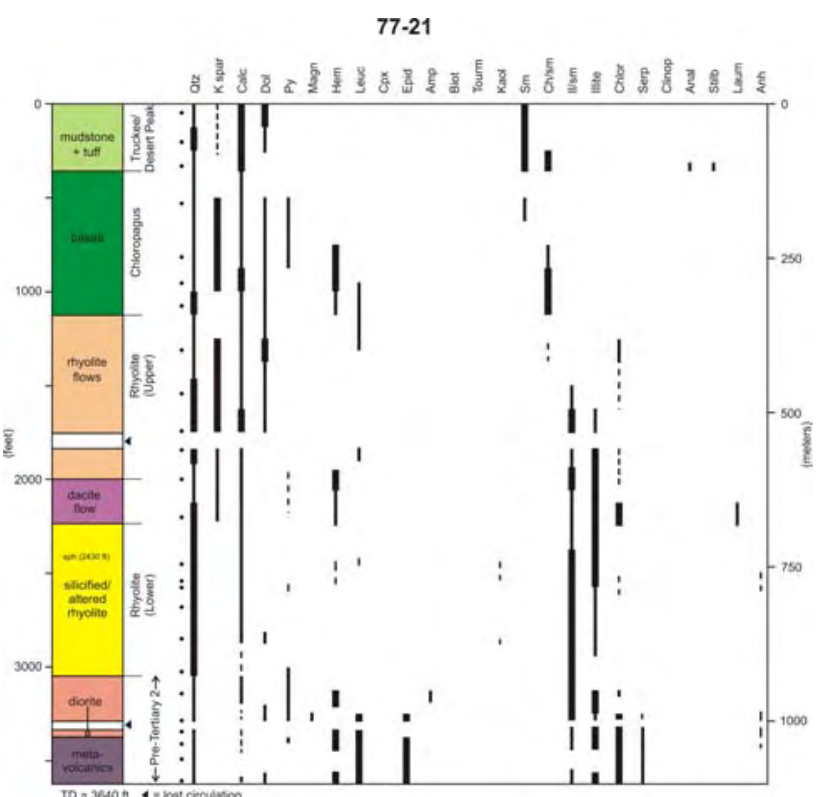

Figure 5: Lithologic column and distribution of secondary and hydrothermal alteration minerals in Well 77-21. Black arrows show the positions of lost circulation zones.

\section{STRATIGRAPHIC RELATIONSHIPS ACROSS THE DESERT PEAK GEOTHERMAL FIELD}

Based on the geological relationships observed in these wells, two cross-sections were constructed (Fig. 6).

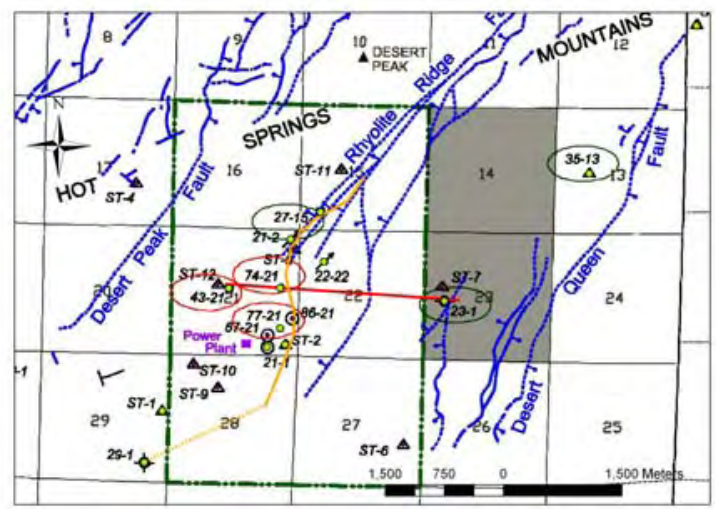

Figure 6: Locations of Desert Peak boreholes used to construct stratigraphic cross-sections. The northsouth cross-section is constructed along wells parallel to Seismic Line 2. 
Here we have liberally borrowed lithologic descriptions from Benoit et al. (1982) to interpret the stratigraphy of outlying wells. For several of the post-1980s boreholes, we also used mudlogs supplied by Ormat to interpret the stratigraphic sequences. The positions of lost circulation zones in the wells are interpreted as fault zones and incorporated into the structural model.

Figure 7 is a conceptual cross-section that shows the stratigraphy and interpreted structure along a constructed cross-section from well 29-1 to the south to well 27-15 to the north. The key features of this section are the gently dipping top of the basement rocks in the north, the presence of pre-Tertiary 1 in well 27-15, and the thick Tertiary section in the southern wells.

Especially notable is the large vertical offset of phyllite and diorite in upper pre-Tertiary 2 sequence between wells 21-1 and 27-15 (located less than 500 $\mathrm{ft}$ apart). At least $1500 \mathrm{ft}$ of displacement occurs between the downdropped basement in well 27-15 and the horst block represented by the Section 21 wells (21-2, 74-21, 43-21, 77-21, and 21-1). Overlying Tertiary strata between wells 27-15 and 21-2 do not appear to be significantly offset, suggesting that development of the horst and subsequent erosion of the uplifted basement occurred long before deposition of the basal Oligocene tuffs (Faulds et al., 2003).

To the south, well logs and lithologic descriptions show a much thickened sequence of Miocene Chlorapagus basalt flows in wells ST-1 and 29-1. This thickening suggests the presence of a preMiocene fault that has downdropped basement rocks to the south. Basalt flows may have filled a paleovalley adjacent to a fault scarp. Thickening of the basalt could also be due to forced folding over a buried basement fault, as suggested by Benoit (1995).

The youngest interpreted faults displace upper Tertiary tuffs (for example, between wells 77-21 and 74-21 (see Fig. 7). A distinctive sphene-bearing rhyolite flow can be used to correlate between wells. This marker bed is present at $2190 \mathrm{ft}$ in 74-21 and at $2430 \mathrm{ft}$ in $77-21$. This $240 \mathrm{ft}$ difference is similar to the offset between the Chlorapagus Formation and the upper tuff contact between these two wells.

Figure 8 is the interpreted cross-section from well 4321 to the west and 23-1 to the east. The major features of this cross-section are the presence of the upper pre-Tertiary 1 sequence and the thick Cretaceous granodiorite in the basement in well 23-1. Compared to the next nearest well on the crosssection (well 74-21), the upper contact with the preTertiary 2 in $23-1$ is downdropped by over $2000 \mathrm{ft}$. The eroded top of the basement rocks gently slopes to the east and overlying Tertiary strata are not significantly offset, at least in a vertical direction. In general, there does not appear to be much expression of the Rhyolite Ridge fault system based on stratigraphic relationships along this east-west section.

The presence of the thick pre-Tertiary 1 sequence of dolomudstones in wells 23-1, 22-22, and proposed EGS-stimulation well 27-15 suggests that the fault controlling the northern boundary of the horst block trends west to northwest. This fault separates the productive Section 21 wells to the south from nonproductive (but still hot!) wells north of the basement fault.

\section{HYDROTHERMAL ALTERATION}

The hydrothermal alteration assemblages shown in Figures 3-5 reflect multiple periods of alteration at different temperatures. As noted above, the presence of tourmaline, biotite and amphibole implies alteration by high-temperature magmatic fluids $(>325$ ${ }^{\circ} \mathrm{C}$ ). Propylitic (epidote-chlorite) alteration and iron oxide (hematite) mineralization is characteristic of the extensive Jurassic hydrothermal system that affected metamorphic rocks of the Humboldt Mafic Complex. These minerals show no relationship to present-day conditions and their distributions are restricted to the Pre-Tertiary 2 unit. In contrast, both the clay minerals and the zeolites display progressive changes with depth and temperature in the modern geothermal system. Stilbite, analcime, and clinoptilolite occur in shallow tuffaceous rocks whereas laumontite veins are found in the deeper reservoir rocks. The presence of low-temperature minerals: zeolites, smectite, interlayered chloritesmectite, and dolomite characterizes the alteration assemblage at shallow depths. Interlayered illitesmectite occurs at intermediate depths, followed by illite. No higher temperature geothermal minerals such as epidote or wairakite are found in any of the study wells. The clay and zeolite minerals are consistent with present reservoir temperatures of $\sim 220^{\circ} \mathrm{C}$. We therefore interpret these minerals as being geothermal in origin. Geothermal veins consist primarily of calcite, dolomite, chalcedony, and zeolites, with minor anhydrite in well 77-21.

\section{DISCUSSION}

Rock-based investigations of the Desert Peak geothermal system are providing new insight into the structural setting of the resource.

The horst model described here is consistent with the earlier Benoit et al. (1982) structural model based on the distribution of subsurface lithologies in the geothermal boreholes. Extensive field mapping of 
Tertiary rocks and gravity surveys conducted by Faulds and Opplinger $(2002,2003)$ provide further evidence the Desert Peak geothermal reservoir is developed in a basement horst.

Recent seismic surveys by Blackhawk Geophysics have imaged several major faults in the Desert Peak geothermal field. The seismic lines show at least one steeply-dipping fault between wells 21-2 to the north and 77-21 to the south that shows large displacement within basement lithologies, presumably where preTertiary 1 mudstones are against pre-Tertiary 2 metamorphic rocks along the fault. Along the SENW Seismic line (Line 2), two subparallel faults are imaged in the Tertiary section between wells 23-1 and 86-21 that extend to the surface. These dip steeply to the northwest and are thought to represent the southeastern-most strands of the Rhyolite Ridge fault system (based on mapping by Faulds et al., 2003).

Recent tracer studies (Peter Rose, Status Report for Tracer Testing in the Desert Peak Geothermal Field, DOE January 2009) show that tracer injected into well 22-22 returned to well 74-21 almost immediately, followed by later returns to well 67-21. Tracer injected into well 21-1 also reached well 7421 , but much later and in low concentrations. The tracer tests seem to indicate strong fluid flow along a NE-trending strand of the Rhyolite Ridge fault system from $22-22$ to $67-21$, which is isolated from an eastern fault block containing wells 21-1, 77-21, and 86-21.

So far, it seems that the NW-SE basement fault that separates non-productive rock to the north from productive wells in the horst to the south controls the depth and distribution of Jurassic reservoir rocks, but not the fluid flow. The fluid flow appears to be controlled by NE-trending open structures related to the Rhyolite Ridge Fault system. The productive portion of the Desert Peak geothermal system is where Jurassic reservoir rocks in the basement occur in an uplifted horst block that is fractured along NEtrending structures.

Geophysical $\operatorname{logs}$ acquired for structural and stress analysis of well 27-15 include Advanced Logic Technologies Borehole Televiewer logs (Davatzes and Hickman, 2009) and Schlumberger Formation Microscanner (FMS) image logs (Kovac et al., 2009). In 27-15, temperature/pressure/spinner (TPS) logs reveal fluid flow at about $4800 \mathrm{ft}$ at the contact between shale in pre-Tertiary 1 and Jurassic diorite in pre-Tertiary 2, where we have previously inferred the presence of a Mesozoic thrust fault based on the sharp contact between thermally-metamorphosed, tourmaline-bearing rocks in the lower plate (preTertiary 2), and weakly metamorphosed mudstones in the upper plate (pre-Tertiary 1). FMS images identify a large open fracture at the lithologic contact with conductive material along the fracture. Based on our petrographic analyses, we interpret the conductive layer as chloritic clay fault gouge within the older fault zone. The presence of open natural fractures and minor fluid flow along this surface indicates reactivation of the older fault plane in the current stress regime (see Davatzes and Hickman for a more comprehensive analysis of the stress regime in well 27-15). The fracture has a NNE-SSW orientation and dips about $50^{\circ}$ to the west which is essentially parallel to the Rhyolite Ridge fault system expressed at the surface.

\section{CONCLUSIONS}

The productive portion of the field lies within a structural horst, bounded by northwesterly-trending faults. These faults affect the basement and the depths of Jurassic reservoir rocks but do not extend to the surface within the field. The northern boundary fault of the horst block does not appear to offset overlying Tertiary rocks. It is not yet known whether this fault is a barrier or conduit to geothermal fluids. Tracer data however indicate that injected fluids can cross this fault zone along structures parallel to the Rhyloite Ridge fault system. Fluid flow in the reservoir is controlled by NNE-trending open fractures associated with the Rhyolite Ridge fault system.

The basement rocks in the proposed stimulation interval in 27-15 are composed of two pre-Tertiary rock units, an upper unit of incompetent mudstones and a lower sequence of diorites and hornfels. Numerous open natural fractures and minor fluid entries are encountered only in the lower sequence. Many of the fractures occur along lithologic contacts and may represent reactivated older fault zones that have opened in the current stress regime. 


\section{REFERENCES}

Benoit, W.R., Hiner, J.E., and Forest, R.T., 1982, Discovery and geology of the Desert Peak geothermal field: A case history: Nevada Bureau of Mines and Geology Bulletin 97, 82 p.

Benoit, D., 1995, Forced folding and Basin and Range geothermal systems: Geothermal Resources Council Transactions, v. 19, p. 155-163.

Browne, P.R.L., 1993, Application of mineralogic methods to access thermal stabilities of geothermal reservoirs: Eighteenth Workshop on Geothermal Reservoir Engineering Stanford University, Stanford, California, p. 73-78.

Davatzes, N., and Hickman, S., 2009, Fractures, stress, and fluid flow prior to stimulation of Well 2715, Desert Peak, Nevada, EGS Project: Proceedings, Thirty-Fourth Workshop on Geothermal Reservoir Engineering Stanford University, Stanford, California, February 9-11, 2009 SGP-TR-187

Faulds, J.E., Garside, L., Johnson, G., Muehlberg, J., and Oppliger, G.L., 2002, Geologic setting and preliminary analysis of the Desert Peak - Brady geothermal field, western Nevada: Transactions Geothermal Resource Council, v. 26, p. 491-494.

Faulds, J.E., and Garside, L.J., 2003, Preliminary geologic map of the Desert Peak - Brady geothermal fields, Churchill County, Nevada: Nevada Bureau of Mines and Geology Open-File Report 03-27.

Faulds, J.E., Garside, L., and Oppliger, G.L., 2003, Structural analysis of the Desert Peak-Brady Geothermal Fields, northwestern Nevada: Implications for understanding linkages between northeast-trending structures and geothermal reservoirs in the Humboldt structural zone: Geothermal Resources Council Transactions, v. 27, p. 859-864.

Johnson, D.A., and Barton, M.D., 2000, Timespacedevelopment of an external brine-dominated, igneous-driven hydrothermal system: Humboldt Mafic Complex, Western Nevada: Part 1. Contrasting Styles of Intrusion-associated Hydrothermal Systems, Dilles, Barton, Johnson, Proffett, Einauldi, eds., Society of Economic Geologists Guidebook Series, Volume 32, p. 127-143.
Kovac, K., Lutz, S.J., Drakos, P. S., and RobertsonTait, A., 2009, Borehole image analysis and geological interpretation of selected features in Well DP 27-15 at Desert Peak, Nevada: Pre-stimulation evaluation of an Enhanced Geothermal System: Proceedings, Thirty-Fourth Workshop on Geothermal Reservoir Engineering Stanford University, Stanford, California, February 9-11, 2009SGP-TR-187

Lutz, S.J., A. Schriener Jr., D. Schochet and A. Robertson-Tait, 2003. Geologic characterization of pre-Tertiary rocks at the Desert Peak East EGS project site, Churchill County, Nevada. Transactions, Geothermal Resources Council, Vol. 27, pp.865-870.

Lutz, S.J., Robertson-Tait, A., and Morris, C.L., 2004, Stratigraphic relationships in Mesozoic basement rocks at the Desert Peak East EGS area, Nevada: Proceedings, Twenty-Ninth Workshop on Geothermal Reservoir Engineering Stanford University, Stanford, California, January 26-28, 2004 SGP-TR-175

Robertson-Tait, A., S.J. Lutz, J. Sheridan and C.L. Morris, 2004. Selection of an interval for massive hydraulic stimulation in well DP 231 , Desert Peak East EGS project, Nevada. Proceedings, TwentyNinth Workshop on Geothermal Reservoir Engineering, Stanford University, pp. $216-221$.

Speed, R.C., and Jones, T.A., 1969, Synorogenic quartz sandstone in the Jurassic mobile belt of western Nevada: Geological Society of America Bulletin, v. 80, p. 2551-2584.

Willden, R. and Speed, R.C., 1974, Geology and Mineral Deposits of Churchill County, Nevada, Nevada Bureau of Mines and Geology Bulletin 83, $95 \mathrm{p}$. 